\title{
A ROTA DO INDIVÍDUO: PENSAMENTO GEOGRÁFICO E GEOGRAFIA DA CIÊNCIA NO PERCURSO DE PERSONAGENS "ANÔNIMOS"
}

\author{
Dante F. C. REIS JUNIOR ${ }^{1}$
}

\section{Resumo}

Neste artigo, centrado numa estada científica na cidade francesa de Montpellier, radiografamos a trajetória intelectual de um geógrafo. A intenção é demonstrar ser possível identificarmos tópicos epistemológicos-chave (que denominaremos "universais") na biografia profissional de personagens que, a princípio, poderíamos entender como sem status de protagonistas (isto é, merecedores de constar em manuais historiográficos). A utilidade deste exercício - já percebida nos estudos filosóficos e sociológicos de outras ciências -, reside no fato de, a partir dele, estimularmos um ângulo de abordagem que ainda não se encontra formalmente estabelecido no âmbito da história do pensamento geográfico. Aqui, devotamos especial atenção ao interessante percurso do personagem Gilbert David, geógrafo do IRD, Institut de Recherche pour le Développement. Por esta ênfase em sua rota, testamos um protótipo para estudos híbridos sobre "história local da ciência" (ou simplesmente "geografia da ciência) e sobre "personagens" desta mesma ciência. David.

Palavras-chave: Estudos biobibliográficos. Geografia da ciência. Montpellier. Gilbert

\section{Résumé \\ La route de l'individu: pensée géographique et géographie de la science dans le parcours des personnages "anonymes"}

Dans cet article, centré sur un séjour scientifique à Montpellier, ville française, nous radiographions la trajectoire intellectuelle d'un géographe. L'intention est de démontrer qu'il est possible d'identifier des sujets épistémologiques clés (que nous appellerons "universels") dans la biographie professionnelle des personnages qui, à première vue, pourraient être compris sans statut protagoniste (méritant d'être inclus dans les manuels historiographiques, donc). L'utilité de cet exercice - déjà perçue aux études philosophiques et sociologiques d'autres sciences - réside dans le fait que nous en stimulons un angle d'approche qui n'est pas encore formellement établi dans le cadre de I'histoire de la pensée géographique. Ici nous portons une attention particulière à I'intéressant parcours du personnage Gilbert David, géographe de I'IRD, "Institut de Recherche pour le Développement". Pour cet accent mis sur son itinéraire, nous testons un prototype pour les études hybrides sur I" histoire locale des sciences" (ou simplement "géographie des sciences") et sur les "personnages" de ces mêmes sciences.

Mots-clés: Études biobibliographiques. Géographie de la science. Montpellier. Gilbert David.

\footnotetext{
1 Departamento de Geografia, Universidade de Brasília - Campus Darcy Ribeiro, Mezanino do ICC Norte, 70910-900, Brasília/DF - E-mail: dantereis@unb.br
} 


\section{INTRODUÇÃO}

Entre os meses de Janeiro e Fevereiro de 2017, estivemos na cidade francesa de Montpellier (Região do Languedoc-Roussillon, Sul do país), onde, gentilmente, os pesquisadores da Unidade Mista de Pesquisa "ESPACE-DEV" ("Espaço a Serviço do Desenvolvimento"), lotados na "Maison de la Télédétection"2, nos receberam para que pudéssemos interagir com suas atuais investigações ali. Esta Unidade foi criada no início dos anos 2000, objetivando tratar da "espacialização" de dinâmicas socioambientais; para tal, reúne três "Équipes", e uma das quais nos incitou um plano de investigação: a equipe definida pelo sugestivo acrônimo "AIMS" ("Abordagem Integrada dos Meios e das Sociedades"). A Unidade surgiu de uma associação de pesquisadores que trabalhavam com sensoriamento remoto e temas ligados a ambientes litorâneos; enquanto a referida equipe sua integrante derivou também da fusão de dois grupos antecedentes, os quais se interessavam pelos temas "paisagem" e "gestão integrada dos litorais" - constituindo um ambiente, à época, certamente muito estimulante: incumbidos, a princípio, de pesquisas de ordem metodológica, os integrantes podiam lançar seu olhar a florestas, desertos, mares ... em busca de um método genérico para compreender as relações entre as sociedades e os meios.

Boa parte dos pesquisadores que integra a referida UMR sediada em Montpellier está vinculada ao IRD, que substituiu o antigo e famoso ORSTOM ("Escritório de Pesquisa Científica e Técnica Além-Mar"), atuante desde os anos 1940. Trata-se, portanto, de um órgão diretamente ligado a um ideário governamental de extensão e gestão racionalizadas; e de uma ciência, então, que vai ao encontro da sociedade civil, posto que deve estar "a serviço de..." - melhorias socioeconômicas locais, normalmente. $E$, no caso do IRD, pensou-se sobretudo nos territórios que fizeram parte da história colonial da França (daí, aliás, muitos dos empreendimentos do Instituto, e antes do Escritório, terem sido chancelados por Ministérios, tais como o de "Assuntos Estrangeiros"). Cabe destacar a contribuição que uma série de geógrafos deram à visibilidade e excelência do Institut de Recherche pour le Développement; dentre eles, Jean-François Richard - pedólogo-geógrafo que jogou o extraordinário papel de praticamente recriar, por conta própria, uma "science du paysage"4.

A ideia central que move esta espécie de instituição (cuja natureza, aliás, é o que justifica nosso interesse em aborda-la) é o de configurar uma expertise que faça as vezes de interface "conhecimento-decisão". Balanceando as vantagens que podem advir, seja de uma pesquisa fundamental (que desfruta de maior grau de "liber-

\footnotetext{
2 O "Espace-Dev" é instituição chancelada pelo Governo francês sob a assinatura de "Unidade Mista de Pesquisa" (UMR-228), via CNRS, o "Conselho Nacional de Pesquisa Científica" daquele país. Há integrantes que se encontram em outras unidades, por exemplo localizadas na Guiana Francesa e no Departamento de Reunião. A sede oficial, porém, fica em Montpellier, e instalada, junto com outras Unidades de Pesquisa (praticamente todas elas vinculadas à espacialização da informação) na chamada "Casa do Sensoriamente Remoto". Mais informações em: <https://www.teledetection.fr/>.

3 Estabelecimento público técnico-científico que exemplifica um caso de "EPST" (Établissement Public à Caractère Scientifique et Technologique) criado pelo governo francês nos anos 1980.

4 J.-F. Richard (1947-) personificou, de certa maneira, a diferença entre as pedologias francesa e americana - esta última, contextualmente, bastante abastecida pela landscape theory desenvolvida por ecólogos anglo-saxões. Mas dada a complexidade de sua proposição de abordagem, não encontrou continuadores. Três de suas mais notáveis produções bibliográficas são: "Essai de définition de la géographie du paysage" (Paris: CNRS, 1973. 80p.), "Paysages, écosystèmes, environnement: une approche géographique" (L'Espace Géographique, v. 4, n. 2, p. 81-92, 1975) e "Le paysage, un nouveau langage pour l'étude des milieux tropicaux" (Paris: ORSTOM, 1989. 210p.).
} 
dade"), seja de um estudo aplicado5. É certo que costuma ainda haver uma impressão de dicotomia entre os papéis a serem jogados por uma "communauté scientifique", que tem intenções de reconhecimento internacional (e isso não necessariamente vai pressupor um engajamento com demandas da sociedade), e por um quadro de experts em pesquisa aplicada; os quais (tenderíamos a pensar) vão obrigatoriamente orientar suas ações técnicas conforme as circunstâncias o exigirem - isso podendo significar também que, às vezes, enquanto a esfera da expertise conta com direto suporte dos poderes públicos e orgãos internacionais, aquela "comunidade" é simplesmente uma consumidora desses trabalhos aplicados. Tema que a sociologia da ciência aponta como de alta relevância; visto que tenderiam a ser muito relativas as percepções de "legitimidade" conferida a uma e outra modalidade de prática científica 6 . Bem como de "status": é normal que o grande público, assim como a intelectualidade acadêmica, nem tomem conhecimento dos préstimos realizados pela expertise. Gilbert David, em todo caso, nos diz ter adquirido toda a sua experiência com Unidades de Conservação - e, por sinal, justo num momento em que elas viram o dia em territórios do Oceano Indico - precisamente graças à prática da expertise.

Seguindo um exercício que vimos executando nos últimos anos (e que já nos proporcionou contatos esclarecedores com personagens das cidades de Toulouse, Avignon e Besançon ${ }^{7}$ ), quisemos inventariar agora o caso Montpellier. É que as historiografias realmente nos destacam um elemento que é altamente significativo do ponto de vista da análise metacientífica: o fato de que, às vezes, num mesmo país, mas em "distintas geografias", acaba dando-se a erupção de certa especialidade regional de pesquisa, eventualmente consolidada em "villes universitaires" (DENEUX, 2006). Assim, se Grenoble pôde instituir uma geografia "alpina" e Bordeaux uma "tropical" consagrada a ilhas e compartimentos africanos, Montpellier também desenharia para si certo timbre identitário.

Montpellier, por exemplo, está muito vinculada às produções iniciais (mas já promitentes) de um Maximilien Sorre (1880-1962), oferecia muitas mais perspectivas a explorar. Sorre, nome que está por trás de um olhar precursor (e praticamente solitário à época) a respeito da convergência aplicada entre Geografia e Biologia, nos anos 1900 e 1910, teve uma passagem inspiradora por Montpellier. Podemos, inclusive, afirmar que é a partir daquela "geografia" que ele desenvolve os elementos de sua sustentação mais vívida: a ideia de que uma Geografia utilitária deveria estar bem posicionada entre os estudos de ecologia humana e de medicina tropical. E que a tarefa da própria geografia humana deveria ser a de considerar o homem como "organismo vivo" que, mesmo reagindo aos estímulos e excitações do meio físico, está invariavelmente submetido a determinadas condições de existência vinculadas a este mesmo meio.

\footnotetext{
${ }^{5}$ A exemplo de outras entidades francesas, reconhecidas por instituições governamentais, O IRD atua por "Unidades" que podem ser "de Pesquisa" (as "URs", Unités de Recherche) ou "de Serviço" (as "USs", por sua vez, Unités de Service). Grosso modo, as primeiras destinam-se a investigações de base; enquanto as segundas, à pesquisa metodológica posta a serviço de demandas sociais locais.

6 Efetivamente, um dos temas tradicionais explorados pela sociologia da ciência é a discussão sobre o sentido de se defender ainda o cânone do "desinteresse". Ou, o quanto não seria ingênuo pensarmos na resistência de um "pesquisador universitário", imune ao fato de que empresas e governos (porque desejam responder aos problemas) necessitam precisamente de mão-de-obra científica especializada; e que uma vez que essas organizações estimulam a criação de postos de "pesquisador aplicado", isso também acaba encorajando e reabastecendo a própria pesquisa fundamental (GINGRAS, 2013).

7 Esta mesma revista Geografia (ISSN 0100-7912) concedeu-nos a chance de divulgar à comunidade brasileira os resultados de nossas interações com a academia francesa. Artigos relacionados às estadas naquelas três cidades são encontrados nos seguintes volumes: 32 ( $n$. 2) - caso Toulouse; 37 (n. 3) e 38 ( $n .1$ ) - caso Avignon; e 39 (números 2 e 3) e 40 (n. 1) - caso Besançon.
} 
É bonito notar que na introdução de um dos tomos de sua obra clássica, "Les fondements biologiques de la géographie humaine" - cuja primeira edição (1943) tivemos o prazer de folhear no Centro de Documentação do Departamento de Geografia e Planejamento, da Universidade Paul-Valéry (Montpellier 3) -, o autor, além de referir-se aos "acasos e vaivéns" da vida do cientista (algo que nos interessa aqui), valoriza a cidade que the ambientou a redação da futura Tese sobre os Pireneus mediterrâneos, bem como os primeiros rascunhos que viriam a constituir aqueles "Fundamentos...":

Je livre cet ouvrage au lecteur. J'en ai entrevu les premiers thèmes dans la douceur du ciel montpelliérain avant 1914, en un temps où l'allégresse de penser était pure de toute mélange. Je I'ai poursuivi sans relâche à travers les vicissitudes d'une carrière dont chaque épisode a apporté une contribution nouvelle à l'élargissement de mon dessein ${ }^{8}$. (SORRE, 1943, p. 10).

Mais adiante no tempo, e se atentos precisamente aos últimos trinta anos, fatalmente teríamos de pôr Roger Brunet sob nossa lente analítica. Ele, sem qualquer dúvida, contribui à institucionalização da Geografia acadêmica praticada em Montpellier. Um dos principais idealizadores da célebre revista L'Espace Géographique (1972), Brunet, sensível aos anseios e aportes metodológicos da Nouvelle Géographie, desejou refundar, fora do polo parisiense, o clássico projeto das "géographies universelles". Em vestes doravante "mais científicas", esta quarta versão teria o desafio de suceder os empreendimentos executados ou dirigidos por um Conrad Malte-Brun (entre 1810 e 1829), um Elisée Reclus (entre 1875 e 1893) e por um Lucien Gallois (entre 1927 e 1948) - este último, a partir de projeto originalmente desenhado por Vidal de La Blache (DEPREST, 2005). A "Geografia Universal" de Brunet contaria com dez volumes, aparecidos entre 1990 e 1996. Alinhado com a perspectiva da "organização do espaço", assentada no paradigma das análises estruturalista e hipotético-dedutiva, este notável personagem encabeçou ainda uma série de publicações, vindas a público com a assinatura "GIP-RECLUS" - que era, simultaneamente, uma homenagem ao "grand géographe" Élisée Reclus e um oficial "Grupo de Interesse Público" (GIP) que estimava poder ter impactos no ensino e no planejamento. Nos anos derradeiros do Grupo, na década de 1990, ele foi dirigido pelos geógrafos Hervé Théry, Frank Auriac e Joël Charre (estes dois últimos, a exemplo do próprio Brunet, tendo sido protagonistas da difusão, da França, da "Géographie Théorique et Quantitative"). O Grupo esteve ativo entre 1984 e 1997. Em parceria com outros importantes nomes franceses (tais como Robert Ferras), Brunet fundou em Montpellier a "Casa da Geografia" (Maison de la Géographie). Hoje, embora aparentemente abandonada, é mantida, no mesmo endereço, como integrante da chamada Maison des Sciences de l'Homme de Montpellier (MSH-M), onde também se encontram laboratórios e centros associados a três unidades da Université de Montpellier (nas áreas de história, etnologia e psicologia). Ali, desde Montpellier, à estreita rua "Abade da Espada", número dezessete, Brunet quis apontar a necessária reorientação (recentrage) da ciência geográfica.

\footnotetext{
${ }^{8}$ Numa tradução aproximada: "Entrego este livro ao leitor. Pressenti seus primeiros temas sob a doçura do céu de uma Montpellier de antes de 1914; época em que a alegria de pensar ainda estava purificada. Tenho perseguido sem descanso esse entusiasmo, mesmo atravessando as reviravoltas de uma carreira em que cada episódio trouxe uma nova contribuição para o engrandecimento de meu projeto". É interessante notar que a passagem de Sorre por Montpellier também favoreceu seu contato com Charles Flahault (1852-1935) - botânico e fitogeógrafo, fundador do Instituto de Botânica de Montpellier -; de cujo convívio deve ter sem dúvida resultado boa fração de sua sensibilidade ao fenômeno "vivant" e, portanto, sua vindoura contribuição a uma "géographie biologique" assentada em noções substantivas de Ecologia (SIMON, 2016).
} 

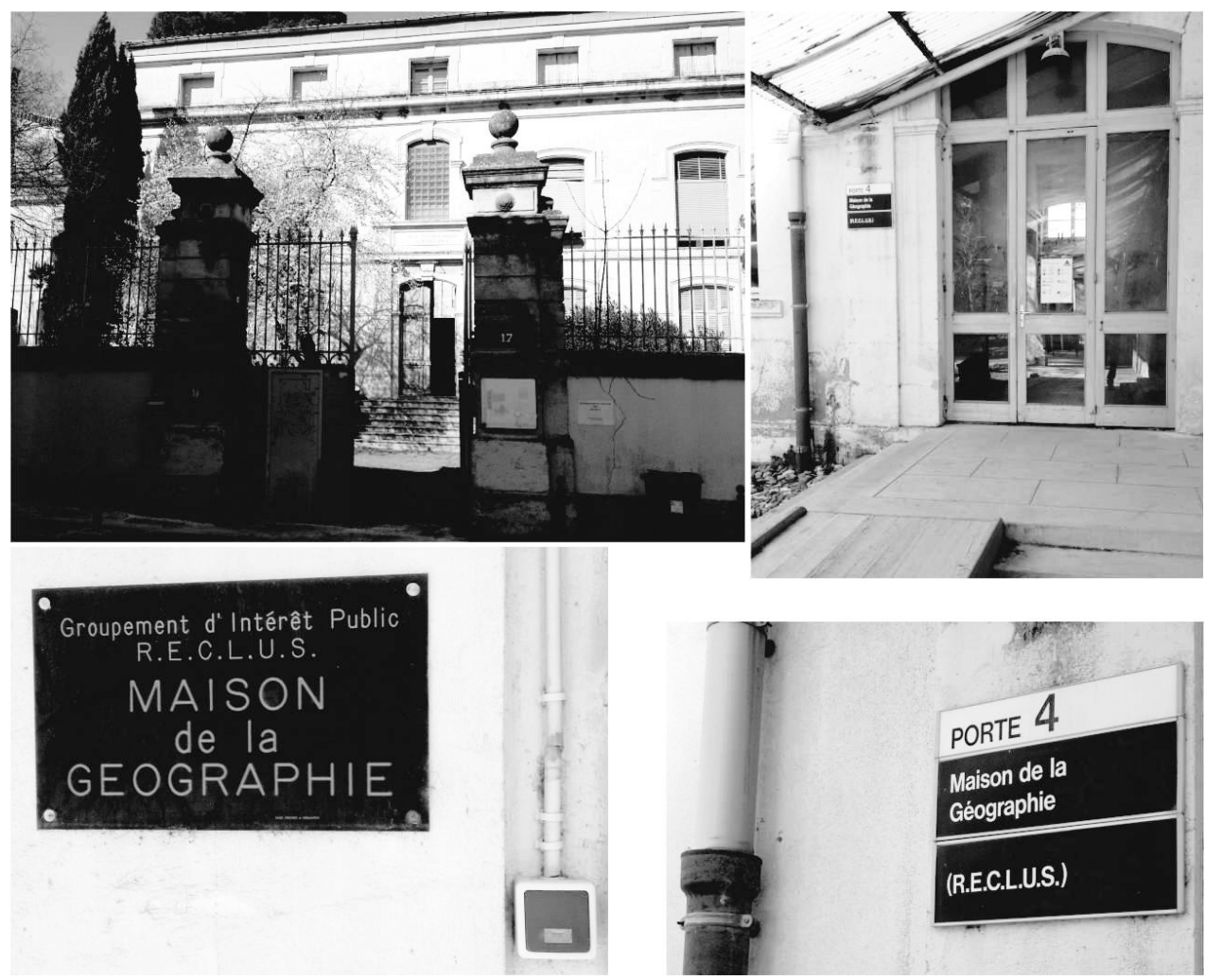

Figura 1 - Instalações da Maison de la Géographie

[fotos de nossa autoria (20 fev. 2017)]

Gostaríamos de frisar que nossa linha de raciocínio aqui se enquadra numa espécie de zona de fronteira entre o que está bem descrito como new sociology of science (apesar de se tratar de uma frente bastante ampla) e os recentes "biobibliographical studies" (os quais têm sido empreendidos com visibilidade no setor particularmente da Geografia). Entendemos assim porque essa modalidade de investigação que vimos empreendendo - fazendo convergirem os exames da produção textual do(s) personagem(ns), seus relatos/depoimentos a propósito das vivências e ainda a incorporação de alguns dados-chave, úteis a iluminar a dimensão conjuntural de seus feitos e ideias - parece se situar mesmo num verdadeiro carrefour multieixos: onde a ambientação sociocultural, as dinâmicas de negociação de controvérsias e o realce aos locais de trabalho ou outras "geografias" em que o cientista faz seus julgamentos e toma suas decisões, têm muito a dizer sobre os "produtos finais", digamos assim, das práticas.

É certo que em meio àquela "nova sociologia da ciência" vamos encontrar propostas até bastante conflitantes entre si - de programas fortes (como os da Escola de Edimburgo, verificados em David Bloor e Barry Barnes) a matizes mais abertos, vistos como relativistas e mesmo etnográfico-construtivistas (como os que encontraríamos já em autores como Steven Shapin, Knorr-Cetina e Bruno Latour) (PESSOA JR., 1993). Mas do seio dela é possível alçar percepções metodológicas caras: 
Uma maneira de estabelecer a identidade de Hooke [Robert Hooke (1635-1703)] [...] é segui-lo ao longo de um dia de trabalho, é traçar os padrões cotidianos de seus passos em ambientes físicos, sociais e culturais. Que trabalho ele fazia e onde ele o fazia? Quais eram as relações sociais que tinha e construía no curso de seu trabalho e qual era a natureza moral dessas relações? Quais eram as ligações entre o ir e vir diário de Hooke [...] É claro que não podemos recriar em sua totalidade um dia na vida de Hooke [...] No entanto, podemos escolher certas características recorrentes de seus passos as quais mantêm importante relação com quem se entendia ser Hooke em seus ambientes [...] (SHAPIN, 2013, p. 185, grifo nosso).

Quanto aos estudos "biobibliográficos", trata-se, como é fácil presumir, de abastecer as investigações acerca da história das ideias e dos pensamentos geográficos com um inventário das trajetórias de personagens pioneiros, por exemplo, em dados contextos nacionais. Isso já se estabeleceu como uma tradição de enaltecimento de "determinados indivíduos" - sendo notável o caso britânico e suas enciclopédias em louvor àqueles que parecem ter jogado importante papel na profissionalização da geografia acadêmica do Reino Unido (GOMES, 2016). A questão, todavia, é discernir o que pode vir a ser um documento que oficializa a celebração de algumas figuras em detrimento de outras, do que pode constituir, diferentemente, um plano original: pôr sob holofotes os outsiders; não menos protagonistas, ainda que noutro viés.

No que diz respeito à geografia das práticas, alguns poderiam certamente argumentar que uma perspectiva centrada no lugar da produção científica não revela nada além do que a sociologia do conhecimento já parece ter sabido explicar. $E$, neste sentido, enfatizar que dada atuação do cientista se deu num determinado local, e não em outro qualquer, poderia significar a minimização da importância de outros fatores operantes. No entanto, é provável que a modelagem teórica sobre esse "localismo" ainda precise ser melhor desenhada e robustecida. Por exemplo, no que tange a detalhes a ver com a difusão espacial do conhecimento, com a amplitude de sua propagação, etc. Por isso o emergente ângulo da Geografia da Ciência ser visto como uma reivindicação totalmente justa (POWELL, 2007).

Para elaborar um documento em tom biobibliográfico, a obtenção dos dados sobre Gilbert David se deu através da realização de três entrevistas (23 e 24 de Janeiro, e 13 de Fevereiro de 2017) e do exame, especialmente, de dois dos três tomos de seu "Mémorial" (DAVID, 2005a; 2005b) - material que organizou e defendeu, a fim de que passasse a estar habilitado a dirigir Teses e Dissertações em seu país. O volume um, em particular, provou-se a fonte mais substancial para o desenho da trajetória do personagem. Pois é ali que David, relembrando seu próprio "itinerário de pesquisador-geógrafo", explica-nos o que o fez tornar-se especialista em mar e ilhas.

David, ao longo da carreira, produziu cerca de 140 documentos - previsivelmente, substantiva fração é constituída de "relatórios técnicos"; e menor porção distribui-se em gêneros de referência científica mais nos moldes que reconheceríamos como "acadêmicos". Aqueles primeiros, aos quais nosso personagem se refere como "littérature grise", são de um contexto em que David atuou intensamente junto a um

\footnotetext{
9 A "grey litterature" é, essencialmente, um gênero de publicação caracterizada por estar fora do circuito comercial acadêmico. Logo, tende a estar associada a documentos governamentais (produzidos por suas agências), mas também se verificando sob a forma de relatórios produzidos por entidades privadas ou por coletivos da sociedade civil (FARACE; SCHÖPFEL, 2010).
} 
ORSTOM ("Escritório de Pesquisa Científica e Técnica Além-Mar") ou IRD que ainda não haviam dado o "giro" no sentido da competição internacional acadêmica; isto é, detinham a insígnia de instituição "parceira" de administrações locais, devendo-Ihes, portanto, resposta direta às suas demandas (quando, então, aquela espécie de documento "cinzento" é a mais funcional e corrente).

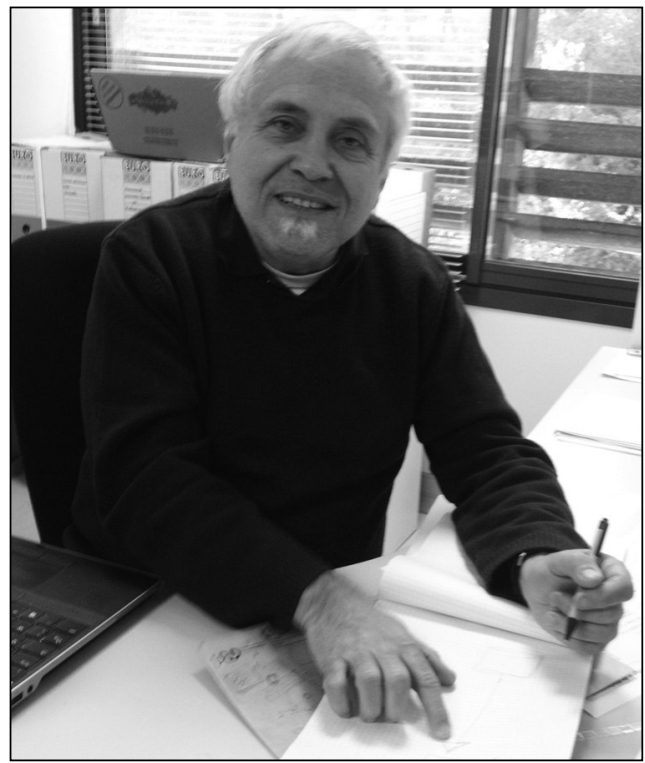

Figura 2 - Gilbert David

[foto de nossa autoria (24 jan. 2017)]

\section{UM GEÓGRAFO, DE NOME DAVID, NA GEOGRAFIA CHAMADA MONTPELLIER}

Montpellier, capital do Departamento do Hérault, Região da Occitânia, testemunhou não simplesmente uma transição, mas um verdadeiro elo entre o "classique", o "théorique" e o "appliqué" - o que também pode ser interpretado como uma "passagem": do "paysage" ao "aménagement du territoire"; do enciclopedismo a uma formação mais profissionalizante de geógrafos. E para ali seriam atraídas gentes (partiIhando esse ideal) vindas de outras geografias.

Os rótulos que espontaneamente colaríamos em Gilbert David, uma dessas "gentes", seriam os de um geógrafo "da pesca", "do litoral" ou, ainda, "das ilhas". Mas depois de quase quarenta anos de carreira, ele poderia com justiça reivindicar o título de "géographe de la mer". Bastante afinados à tradição divisória da Geografia Francesa, estes labels denotam mesmo uma perspectiva que restou incrustada, depois de dois séculos: a tradição, na França, de associar estudos tópicos numa ancoragem regionalista. Daí a landmark da escola francesa, que (p.ex., ilustrada por autores e editoras dos calibres de A. Demangeon, 1872-1940, e da Hachette, 1826-), fará vir a público monografias sobre os gêneros-de-vida e os habitats manifestos na floresta, no deserto, na montanha ... no litoral. Por outro lado, é certo afirmar que a maioria dos geógrafos culturais franceses de linhagem tradicionalista restarão atraídos pelo 
meio rural; isto é, serão, por efeito, reticentes quanto ao investimento intelectual num mundo estranho como o da realidade pesqueira. Restara aberto, assim, um largo e fecundo campo ao nosso personagem.

Numa de nossas conversas, David disse: "não sou um verdadeiro geógrafo; sou um geógrafo nas interfaces". Ao que Ihe retruquei: "mas, então, é um verdadeiro geógrafo". E ele: "bom, mas é que há 'geógrafos verdadeiros' que me enervam um pouco". David se referia ali a geógrafos que só leem geógrafos. Mais além da colocação irônica, sabemos que nós geógrafos - e mesmo na visão de quem nos lança o olhar - temos (ou deveríamos ter, pelo menos) essa capacidade de pôr elementos em conjunto. E daí ficarmos tentados a entender que, com uma mirada assim, de "système", somos os que chegam mais facilmente a identificar e explanar sobre as relações entre eles. E encontrar as sínteses! Mas, talvez, revelando aí uma muito elevada presunção, que nosso personagem censura:

[...] quando os economistas dizem que nós geógrafos sabemos fazer tudo, mas tudo mal, isso não deixa de ser uma crítica interessante. Coloca diante de nós aquilo que parece ser um trunfo da Geografia (o de possuir uma "baía" muito ampla), nos fazendo pensar nos limites deste modo de abordagem. Não é porque temos uma visão "holista" que somos especialistas em sociedade. Não temos necessariamente a bagagem teórica e conceitual para ir mais além. [...] Eu o que faço é geografia cultural, ligando-a ao meio ambiente. [DAVID (Entrevista 13 fev. 2017, tradução nossa)].

David fora aluno, em Brest, de André Guilcher (1913-1993, por sua vez aluno de Emmanuel de Martonne, 1873-1955), quem, sem dúvida, Ihe impregnou com sua longa produção sobre litorais e mares: estudos sobre morfologia e hidrologias marinha e continental. Provavelmente esse contato com um dos grandes notáveis da geografia francesa, contribuiu de modo decisivo a que se orientasse no sentido das abordagens naturalistas. Além, é claro, da própria perspectiva inventariante - procedimento que é patrimônio identitário do exercício geográfico francês. Todo geógrafo, afinal, parece entender que ela (se busca o fiável e o preciso) é exatamente o que lhe garante o apprentissage de seu métier.

Mas o elemento atrator que logo nos fez perceber que aquele personagem mereceria um particular holofote foi sua preocupação com a "gestão integrada" de zonas costeiras. Preocupação que emerge nos anos 1990, em virtude da crescente pressão antrópica sobre os litorais, e que David converteria em ato via métodos de "pesquisa-ação" (a recherche-action) - algo que merece todo o grifo aqui, já que é preciso que a ciência, no final das contas, aporte alguma coisa aos grupos sociais. Essa gestão, entretanto, carece de certos "indicateurs" como guia; exige do cientista aplicado (seu constituidor e usuário) um espírito atento à relatividade destes mesmos indicadores - visto que nem todos, e nem sempre, serão propriamente pertinentes e/ ou eficazes para pôr em marcha as ações locais. Altamente significativa, a expressão encerra dois salientes aspectos: uma clara preocupação com a dimensão aplicada do conhecimento (o ângulo da gestion), complementada pelo evidente entendimento de que esta aplicação precisa se dar num viés de interdependência complexa (o ângulo da intégration). Pensamos que a presença desta inquietação no percurso do personagem aponta também uma espécie de engajamento que só foi diretamente ativado entre geógrafos e cientistas sociais no pós-guerra. Período a partir do qual a própria esfera governamental, associada à ciência, fomentou iniciativas e projetos voltados para respostas diretas às demandas locais.

Por outro lado, um fator personalista não deixa de jogar papel relevante. David, que desde muito jovem militou no discurso e prática ecológicos - tendo participado, 
p.ex., do movimento Bretagne Vivante ${ }^{10}$ e se envolvido em protestos contra as intenções da Prefeitura de Brest, que intentava promover vários loteamentos à beira-mar -, viu que poderia ser interessante conciliar a militância ecológica e os estudos universitários. E é provável que sua visão de mundo tenha muito a ver com a procedência: nascido bretão, seu temperamento pode ajudar a explicar determinadas inclinações. Desconto dado aos lugares-comuns que se infiltram em nossos imaginários sobre os lugares e suas gentes, diz-se correntemente que bretões, embora não exibam sorrisos numa primeira reunião, uma vez estabelecido o elo, deixam ver logo sua joie de vivre e são de uma entusiasmante solidariedade.

David está oficialmente vinculado ao IRD há mais de duas décadas, mas, tomando uma escala de tempo mais dilatada, vemos um percurso que compreende experiências em outros horizontes (heterogêneos e instigantes). Até sua chegada em Montpellier, por volta de 1997, quando seria incumbido de pesquisas sobre o Oceano Índico, vivenciou uma miríade de realidades, cenários por vezes até bem conflituosos - quando testemunhou jogos políticos entre atores locais (independentistas versus legalistas). E quase sempre ao sabor de felizes contingências e fatos inesperados; ingredientes que também o tornam um excelente objeto de análise pela ótica da história da ciência geográfica. Porque "la nécessité et le hasard" compõem mesmo quase sempre nossas trajetórias de vida, e em se tratando de rotas empreendidas por um gosto pela ciência, poderíamos dizer que a "necessidade" estaria definida por certas propensões e preferências do indivíduo em questão (no caso de David, uma indisfarçada afetividade pelas águas); enquanto que o "acaso" operaria como uma espécie de elemento desafiador daquelas inclinações. Que põe à prova, p.ex., a tenacidade, a perseverança do sujeito; interpondo fatores de ordem aleatória. Às vezes até aflitivamente fortuitas, embora podendo criar satisfação a longo termo: um sujeito que, sem planejar, vem a tornar-se especialista na organização espacial da pesca, ou dos recifes de coral.

Um fator, no entanto, é estável em seu percurso: a coordenação das pesquisas fundamental e aplicada; como se, em realidade, na biografia deste indivíduo cientista, fosse simplesmete falso o debate sobre quando uma se verifica (e a outra não). Pelo menos no domínio das geografias litorânea e da pesca a pretensa distinção entre elas só estaria visível do ponto de vista da forma; não do fundo. Posto que David veria em ambas uma mesma (e imprescindível) composição de ações: a descrição, a análise, a modelagem teórica, a discussão crítica (para validar ou infirmar os modelos), o diagnóstico amparado por indicadores entandardizados e, por fim, a recomendação ou aconselhamento - emitidos em prol de colaborar à eficácia das organizações espaciais estudadas.

Por isso a "pesquisa-ação" ser tão cara ao personagem. Porque trabalhar com gestão significa necessariamente trabalhar em parceria com os gestores também.

Eles nos fornecem informação, mas, como há um "retorno", eles também estão interessados pelo nosso olhar "exterior" e pelas informações que possamos lhes dar. E eu penso que, pelo menos em se tratando de meio ambiente, as pesquisas devem se prestar a isso também. Por isso me considero um trabalhador em pesquisa aplicada. Porque considero que trabalho para melhorar a gestão do meio ambiente. [DAVID (Entrevista 23 jan. 2017, t.n.)].

É preciso um olhar distanciado com relação ao que "eles" fazem, mas a partir do momento em que o cientista é um pouco militante, será natural que procure fazer

\footnotetext{
10 Criada em 1958, essa Associação dedica-se à proteção do patrimônio natural da Região da Bretanha. (ver: http://www.bretagne-vivante.org/).
} 
deste contato (com quem toma a decisão pública) uma oportunidade para aclarar suas medidas - a fim de que elas sejam sempre melhores do que possam ter sido antes. "Alguns dirão que isso não é pesquisa! O pesquisador deve permanecer imparcial! [...] É difícil ficar alheio. Embora seja possível manter elos com os sujeitos da pesquisa sem partilhar de seus interesses" [DAVID (Entrevista 24 jan. 2017, t.n.)].

Mirando sua trajetória quando ainda um jovem acadêmico, vemos ali, na iniciação do cientista, ir se esboçando o perímetro de um domínio de interesses. Para sua pesquisa de conclusão de graduação fez trabalhos de campo no Brasil - na Paraíba mais precisamente (onde interagiu, no início dos anos 1980, com comunidades de pescadores). No Mestrado, foi à Costa do Marfim, também na década dos oitenta, praticando já efetivamente uma "geografia da pesca". E a partir do doutoramento, aos arquipélagos do Pacífico (por exemplo, na Melanésia), onde desenvolveu estudos na República de Vanuatu, bem como na Nova Caledônia (tendo iniciado estas últimas expedições durante a primeira metade dos anos 1990).

A construção sistêmica que David desenvolveu, nestas três tomadas de tempo, para a compreensão sistemática do que se passava nas respectivas três realidades, previa a necessidade de incorporar/entender o entrelaçamento dos fenômenos de ordem social - por exemplo, dando atenção ao importante problema da segurança alimentar das comunidades estudadas. Porque logo percebeu que se tratava de cumprir um entrosamento que muitos cientistas esquecem ou deliberadamente negligenciam: integrar aos conhecimentos de tipo "global" (isto é, consagrado e verificado em várias porções da realidade), os conhecimentos "locais" - que, não poucas vezes, corrigem as hipóteses protocolares do cientista, no campo.

Nem todas as questões são globais [...] Podemos ter um conhecimento geral, sobre o que é a cana-de-açúcar, por exemplo, suas condições agronômicas, mas falta a relação entre esse conhecimento global e o campo. Porque o sucesso da plantação não depende simplesmente do conhecimento que você tem da cana, mas da integração desse conhecimento global às condições da situação local. [DAVID (Entrevista 24 jan. 2017, t.n.)].

Outra dualidade, que se apõe a esta do "local versus global", é visível no percurso de nosso personagem: a dissintonia que costuma haver (e precisa ser resolvida num contexto de gestão) entre o conhecimento técnico do cientista, que está ali como investigador/consultor, e o conhecimento dos "gestionnaires"; os atores políticos, eleitos para a administração. Lembrando que, frequentemente, os eleitos não lidam bem com a presença de um cientista que, em teoria, está ali encarregado de uma "aide à la décision". Uma ajuda que acaba tendo uma dimensão temporal que, de fato, não é aquela que o tomador de decisão necessita: o cientista que estaria capacitado a indicar ações no prazo de dois anos, não contentaria um governante que as necessita para amanhã. Sendo assim, a "échange d'information" que tem de se dar prevê uma partilha. Mesmo porque os sujeitos locais, efetivos beneficiários do plano de gestão a ser desenhado, precisam apreender o sentido das informações.

[...] il convient de leur parler un langage qu'ils puissent comprendre, ce que ne sont à l'évidence ni le discours purement scientifique, ni la rhétorique environnementale $[\ldots]$ C'est au géographe de se mettre à portée de ce public, cible de ces travaux [...] (DAVID, 2005b, p. 6, g.n.). 


\title{
REFLEXÕES DE SEGUNDA ORDEM
}

\begin{abstract}
"Second-order questions" são aquelas questões que, em Filosofia da Ciência (FC), dizem respeito mais ao "about science"; não tanto ao "scientific". Ou, colocando em outros termos, definem o setor da análise epistemológica - setor dentro do qual cabem as indagações sobre os limites da ciência, sobre como ela opera (ou deveria operar), sobre qual o alcance de aplicação de seus métodos (ROSENBERG, 2005). Quais, enfim, são as "conditions" para a produção de conhecimento científico; sejam elas internalistas e/ou externalistas (GOLDBERG, 2007).

Bem, e um outro elemento identitário que nos chamou a atenção na narrativa "memorial" que o personagem compôs em texto, foi a menção a autores icônicos do pensamento filosófico e sociológico sobre a prática científica. Essa opção analítica de interpretar episódios (que fazem parte de nossa própria carreira) por intermédio da FC - opção nem tão recorrida por geógrafos franceses - já punha David numa escala diferenciada. Ali aparecem um Paul Feyerabend, um Bruno Latour, mas também um Karl Popper ... suportes para o autor sustentar sua convicção de que a pesquisa geográfica estaria longe de ser governada unicamente pela pura razão.
\end{abstract}

A ciência não é mais que uma trajetória. Os resultados científicos são uma trajetória ... que é refutada e leva à outra coisa. E aquilo que possa parecer intangível às vezes não é intangível. O conhecimento que temos hoje, em relação ao de trinta anos atrás, mudou muito [...] [por outro lado] a ciência também é isso: são "capelas", são ideologias, e os resultados científicos aí dentro são produzidos por "gente"; homens que têm sentimentos, fraquezas. Há relações de força. E isso é interessante [...] A ciência não é algo "desencarnado"; que viveria sua vida sem os pesquisadores. Não, a ciência nasce do pesquisador. E o pesquisador é humano. [DAVID (Entrevista 13 fev. 2017, t.n.)].

A prática dos cientistas seria, com frequência, movida por juízos alheios aos eminentemente racionalistas. Disputas conflituosas; representações díspares, associadas a valores muitas vezes antagônicos que eles atribuem aos objetos de investigação ... por exemplo, ao meio ambiente. Assim como ela, ciência, não preveria o uso de métodos exclusivos ou privativos: em Geografia empregaríamos métodos em combinação ("méta-méthodes"); métodos que provêm de diferentes campos disciplinares. A pesquisa geográfica não haveria de procurar, no entanto, a "verdade" dos fatos, mas antes alguns pontos de vista validáveis em dadas circunstâncias; abertos, portanto, à falsificação. Apesar de precisarem ser minimamente resistentes.

[...] les pratiques scientifiques sont fréquemment inspirées par d'autres considérations que la stricte rationalité scientifique, qu'il s'agisse d'enjeux commerciaux, de jeux de pouvoirs ou tout simplement des perceptions et représentations qu'ont les chercheurs de leur travail. (DAVID, 2005a, p. 195).

Por outro lado, essa prática que nos torna cientistas haveria de guardar compromisso com a fiabilidade da informação que se captura. Digamos, quando estamos a recolher opiniões ou o imaginário dos atores, numa situação dada. Aí precisamos de "dados científicos"; mas nem sempre eles são fáceis de coletar. Com frequência faríamos "científico" o que é apenas "representativo". Passando do mundo do percebido ao mundo do objetivo. "Mas não é porque 'medimos' a percepção que entramos de 
fato no mundo objetivo. Apenas medimos 'uma' percepção" [DAVID (Entrevista 13 fev. 2017, t.n.)].

Considero que há muitas coisas que passam por científicas, mas que não o são. Então não dá para tomá-las da mesma maneira. [...] É preciso estar consciente da robustez da informação. Porque se ela não o é, não vale a pena fazer um modelo. Se inserimos nele coisas "moles"11, do modelo também vão sair dados moles. Modelos não têm a capacidade de "endurecer" os dados. É o dado que faz a pertinência do modelo. [DAVID (Entrevista 13 fev. 2017, t.n.)].

\section{CIENTIFICISMO E PENSAMENTO SISTEMISTA}

Só uma abordagem sistêmica poderia favorecer a identificação e a análise das "lógicas" subjacentes à atividade pesqueira e seus lugares entrelaçados: a aldeia (dos "pêcheurs") e o território (de sua "pêche"). Os recursos, a atividade de captura, o meio social, os poderes públicos, os consumidores ... elementos estes podendo estar ligados aos campos das ciências humanas e da natureza. E esse necessário entrelaçamento de saberes teve em David um efeito interessante: o entendimento de que uma velha concepção epistemológica teria de ser retrabalhada no mundo da efetiva prática científica. A de que as ciências humanas lidam com démarches sobretudo indutivistas; e as exatas e naturais ("mais rigorosas"), com dedutivistas. As primeiras partindo de fatos observados, informações de campo, que depois são relacionadas a fim de obter uma compreensão. As segundas, privilegiando menos (que aquelas) as descrições e elaboração de tipologias - colocando, em posição dianteira, a teoria, que guiará a captação de fatos. Todavia, não seria totalmente correto insistir que as primeiras são, por conseguinte, menos seletivas quanto aos fatos de observação.

[...] toute démarche inductive pour être féconde devrait donc se solder par une théorisation dans sa phase finale. De la même manière, toute démarche déductive qui aspire à élaborer une théorie propre à une région géographique dans le domaine des pêches doit être précédée d'un "balayage" inductif lui permettant d'identifier correctement les phénomènes à étudier. Dans un cas comme dans l'autre, l'essentiel est de porter la plus grande rigueur à la démonstration en mettant l'accent sur l'élaboration de modèles comme construction théorique [...] (DAVID, 2005a, p. 223 , g.n.).

Se dizendo um "caloroso partidário" da abordagem nomotética, David sempre buscou pôr acento nas similitudes e "régularités" - as únicas que, dentro de sua linguagem de águas marítimas, Ihe autorizariam a fazer análises sincrônicas numa escala "oceânica" Por mais que, justamente no âmbito dos estudos de pesca costeira em zona intertropical, não fosse comum essa modalidade de interpretação guiada por

11 David se referia aqui, em parte, ao excesso de confiança que alguns pesquisadores depositam nos "dados declarativos" (données déclaratives), tão centrais nas chamadas enquêtes qualitatives. 
princípios generalizadores. Mas é que tendo assimilado lições de Joël Bonnemaison ${ }^{12}$, ele sabia que mesmo na escala inexpressiva de uma ilha, no seu literal caráter de isolamento, embora nasça daí o estigma da complexidade, reside também um funcionamento do tipo sistêmico - funcionamento complexo de "sócio-eco-sistemas" que não desautoriza a busca de "invariants". Sem dúvida, uma postura que pôs David na contramão do que sustentavam os geógrafos de ilhas de então: ser praticamente impossível lhes identificar caracteres comuns.

A abordagem das monografias é interessante para ter dados precisos. A Geografia de Vidal de la Blache, assim como a Ecologia Humana de nossos colegas ingleses e australianos, fizeram monografias incríveis. Mas elas os levaram a valorizar a diversidade [...] trabalharam as coisas que Ihes pareciam "mais bonitas", "mais espetaculares": ritos mortuários, línguas, etc. Porque havia uma atração do pesquisador pela "diversidade" - que é o que vai distinguir as populações. Por outro lado, tudo aquilo que encontrássemos "na base" não Ihes parecia interessante; então, eles não estudaram isso. O problema das monografias é que supervalorizamos o que é diversidade; e ninguém se atém às coisas que são encontradas na base. [DAVID (Entrevista 13 fev. 2017, t.n.)].

David partira de um ponto de vista totalmente diferente: é preciso buscar os invariantes - que, se não são encontrados no quadro físico, são identificados no comportamento das pessoas e na visão que elas têm do mundo, estando em ilhas ("le comportement insulaire"). É evidente que para o espírito científico reconhecer "ilhas", é necessário de início encontrar "uma" ilha ... e ali "vivre suffisamment longtemps", a ponto de o território tornar-se inteligível (DAVID, 2005b, p. 49).

"Organização", "clímax", "colapso", "reorganização", "resiliência". Mas sociedades humanas funcionariam tal qual ecossistemas? Bem, aí entraria a questão do socioécosystème, mencionado há pouco. E decifrar se coevoluem ecossistemas e sociossistemas restaria o grande desafio aos cientistas teóricos de interface.

Em David, a "modelagem sistemática" (mais do que, restritamente, uma aplicação cega de teoria dos sistemas gerais, enxertada eventualmente de tratamento matemático e/ou fisicalista termodinâmico) significou sempre uma releitura dos espaços a fim de melhor favorecer uma gestão integrada dos territórios. Gestão com a participação dos atores locais, e compreendendo espaços costeiros e marítmos (no mais das vezes, em seu caso, mirando o meio insular). Por isso, aparecer com frequência em seus artigos e relatórios a expressão "système pêche"; assim como é bastante ocorrente a ideia de "sistema cultural reduzido" (système culturel réduit) - no sentido de que do investigador se esperará o realce do que forem exatamente os invariantes ... em meio a uma rica diversidade. Escapando, pois, do que for acidental nas realidades testemunhadas; de modo a "domesticar" o ambiente e desembaraçar a população local dos obstáculos do meio.

Segue daí que a compreensão que veio a ter de modèle encerra uma postura que nos parece bastante equilibrada em seu teor pragmatista: os modelos (estas abstrações representacionais) têm valor na medida em que exprimem "um certo tipo de funcionamento"; e são suficientemente adequados paras os fins que o cientista

\footnotetext{
12 J. Bonnemaison (1940-1997), um famoso geógrafo cultural francês, notabilizado, a princípio, como mestre de uma geografia rural tropicalista, com atuações importantes como Diretor do ORSTOM na Ásia e Pacífico.
} 
Ihes destinou. Noutras palavras, não seria prudente que este profissional acreditasse que sua abstração, seu realismo construído, sintetizasse tudo. "O modelo é um integrador de conhecimentos. Mas não é alguma coisa que sintetiza todo o conhecimento! Ele exprime um nível de funcionamento" [DAVID (Entrevista 24 jan. 2017, t.n.)]. O imaginário de "sistema" em David tem muito mais a ver com uma compreensão de "encaixe"; entendendo-se que convém, decerto, classificar as variáveis potencialmente explicativas, segundo seu pertencimento a um (ou mais de um) dos vários sistemas em consideração.

A elaboração teórica sobre sistemas, em David, respondia ao que lhe pareceu convir a um paradigma miscigenado: ao mesmo tempo, signatário da necessária sustentabilidade dos ecossistemas marinhos e sensível à não menos importante reprodução econômica dos pescadores. Aqui, portanto, insistimos no louvável caráter utilitário que o cientista soube dar às ferramentas de representação e intervenção: empregando-as sob a regência dos valores ecológico e social.

A prática de identificar o que é uniforme, visto pela perspectiva dos systèmes, David absorveu a partir da leitura de autores das cenas fancesa e estrangeira: Edgar Morin, Jacques Monod, Jean-Louis Le Moigne e Georges Bertrand; Ludwig Bertalanffy, Jay Forrester e Eugene Odum. Em cujas obras, ele e muitos de sua geração, souberam capturar úteis aportes.

A ideia de système Ihe conferiu o desejado "quadro conceitual" à sua investigação de Doutorado. E, a bem dizer, uma "inclinaison personnelle" (leituras que fez enquanto ainda jovem graduando) Ihe facilitou as coisas: já assimilava ali a concepção de que os elementos da estrutura qualquer sob análise estão todos estreitamente dependentes uns dos outros; que os conjuntos em questão têm suas partes coordenadas e móveis (de vez que sua interação é essencialmente dinâmica); que a complexidade da estrutura resulta muito da presença de atores múltiplos que a terminam organizando; e que, portanto, essa mesma complexidade emerge do valor diferencial que os sujeitos projetam nos recursos (em conformidade, é claro, com suas heterogêneas capacidades de decisão). Aí residindo, por sinal, a função oportuna das leituras sistêmicas mais sofisticadas; posto que a consideração dos elementos "incerteza" e "conflito" teria de estar presente.

O consenso não existe! Toda decisão pública, no final das contas, é objeto de um compromisso. E é justamente isso a governança resultante. É o decididor político aceitar que seu ponto de vista será objeto de resistência, e que a decisão final será o compromisso entre o que ele quer e aquilo que a população está pronta para aceitar. [...] E é interessante a "arena" onde tudo isso se discute, porque as pessoas quando vão lá, pensam sempre que seus pontos de vista estarão à frente de todos os outros. [DAVID (Entrevista 24 jan. 2017, t.n.)].

Se David não seguiu muito à risca as prescrições exatas da modelagem sistêmica é porque entendeu fazer mais sentido "filtra-las". E isso parece ter se dado, especialmente, com respeito aos aportes que identificou junto à bibliografia inglesa. De fato, ele não incorporou todas as tendências ventiladas dali: a modelagem matemática, com vistas a fazer previsões de comportamentos; o cálculo de performances ótimas, a fim de apoiar a gestão. Entendera que a complexidade inerente aos litorais e às ilhas embaraçava a matematização; ou pelo menos o gênero predominante (algo "linear") dos modelos desenhados. Reteve antes os insights sobre cibernética e a noção de black-box - com suas entradas e saídas, e enigmáticas fronteiras. Praticou o exercício analítico da demarcação; discernindo o que era élément, do que era seu environnement: o clima, o meio marítimo, as jurisdições administrativas, a demografia, 
a história política, a atividade industrial. Mas desde o início intuíra que precisaria, em muitos casos, forjar sua própria representação; detectando e pondo em saliência o(s) elemento(s) do modelo que capitaniaria(m) a dinâmica em questão.

Apropriou-se dos conceitos de "résilience" e "vulnérabilité", de ascendências igual ou aproximadamente sistemistas, e bem difundidos na literatura interdisciplinar - conquanto isso redunde, nos dias de hoje, em embaraçosa polissemia. A capacidade da estrutura em absorver perturbações; o grau de exposição a perigos contingentes (os aléas) .... e essas perturbações e acasos podendo mesmo ser acolhidos teoricamente pela temática emergente dos "risques naturels" - concepção que David diz ter contribuído a alargar sua visão de geógrafo.

O sistemismo pareceu-lhe também um caminho para escapar a armadilhas interpretativas; como a da força (determinista) do "milieu naturel". Põem-se à frente, assim, as faculdades adaptativas, movidas por uma dialética entre os obstáculos e o desenvolvimento de práticas suas contornadoras. E é convencido da necessidade de ponderar as relações entre os fatores humanos e os fatores físicos que, a partir dos anos 1990, David adotaria voluntariamente o termo "socio-système". Posicionandose contra, portanto, às posturas que ignoram a "territorialité" das realidades humanas locais.

\section{GEOGRAFIA APLicAda (NÃo EXATAMENTE HUMANA, MAS "HUMANIZADA")}

É verdade que a presença de pesquisadores e quadros técnicos estrangeiros (franceses, neste caso) em realidades "outre-mer", por força de episódios geopolíticos bem documentados pelas historiografias, nos leva a pensar sempre em ingerências com segundas intenções. Contudo, em boa parte dos casos esta espécie de presença não precisa ser lida de modo pessimista: a pesquisa executada naquelas realidades pode responder a demandas sociais; e estas sendo formuladas por atores entendidos como verdadeiros parceiros ("partenaires $d u$ Sud", diriam alguns). Trata-se de operar diagnósticos que apontam a predominância ainda de modos ineficientes de exploração econômica; demonstram as alternativas para contornar os "nós", os obstáculos que levam a uma exploração inábil. Tudo a partir de conhecimentos científicos de excelência - de cuja aplicação devem derivar resultados perfeitamente acessíveis àqueles atores. Porque os cientistas colaboradores aplicarão seus saberes na medida em que seus "parceiros" codefinem os próprios temas a serem estudados. Numa verdadeira dinâmica de "connivence", no bom sentido do termo. E isso quer dizer que não se trataria mais, simplesmente, daquele tradicionalista olhar alienígena lançado aos trópicos: compondo inventários que identificavam os meios e seus usuários locais; estimando o valor socioeconômico derivado de cada tipo de uso regional. Mais do que isso - e num estilo de visão que pudemos identificar em David -, trata-se de uma operação bastante delicada para quem investe sua energia intelectual nesse gênero de pesquisa-ação. Posto que costuma entrar em jogo o aspecto da "aceitação social" do dado científico, de um lado haverá atitudes tendentes a sobrevalorizar o diagnóstico do cientista ecologicamente sensível ("tal área deve ser protegida"), mas, de outro, conclusões "técnicas", assim taxativas, poderão tender a desencadear também uma resistência local daqueles sujeitos; os quais, quem sabe, descendentes de já muito antigas gerações de exploradores dos recursos, não quererão ver seu território ganhar status de "santuário". 
Então, é o conhecimento científico sendo confrontado com os interesses das pessoas. [...] Quando trabalhamos com "áreas protegidas" muitas vezes o conhecimento científico assume um valor claramente superior ao interesse das pessoas. No entanto, se atribuímos a esse conhecimento um "fator cinco" e ao interesse das pessoas um "fator um", não haverá área a ser protegida. [...] Então seria preciso tentar ver de que modo esse conhecimento científico pode ser modificado para chegar a um "compromisso" com as pessoas. Por isso é que não estou na pesquisa científica "pura", mas mais na utilização do dado científico para objetivos de gestão. [...] É preciso colocar esse conhecimento científico num "debate" entre cidadãos, para que perca seu status de conhecimento "sábio". Agora, isso não quer dizer que ele deve ser discutido em seu "conteúdo"; mas sim na sua "utilização". [DAVID (Entrevista 13 fev. 2017, t.n.)].

Entretanto, nem sempre a perspectiva da gestão é entendida como diretamente atrelada ao papel dos geógrafos (mesmo aqueles atuantes no IRD). É que persiste, ainda assim, o imaginário de que o domínio preciso do profissional atuante nestas instituições é o da pesquisa; e que "gestão" fica a cargo de atores outros. David, contudo, não dá tanta importância a detalhes semânticos; emprega sem pudores a expressão "gestion integrée" entendendo-a como um objeto de estudo para o qual o conhecimento dos geógrafos (na sua forma tradicional de síntese ordenada) tem muito a contribuir. E isso por mais que boa parte dos homens e mulheres de ciência não pareça realmente muito "confortável" na criação do hábito de participar ativamente da esfera da gestão.

D'une manière générale, les scientifiques ne sont pas assez présents et doivent investir le champs de la gestion intégrée des littoraux afin de fournir des concepts, des outils et des méthodes de travail aux gestionnaires du littoral, bien souvent désamparés face à la complexité des éco-sociosystèmes. (DAVID, 2005b, p. 175).

Acrescente-se que, diferentemente da imagem social de outros cientistas (digamos, a do biólogo ou do economista), a princípio o grande público não espera que o geógrafo - e talvez se possa considerar o mesmo para o antropólogo - tenha o que dizer aos exercícios profissionais de formulação de políticas de gestão. No que tange ao nosso campo disciplinar em especial, um pouco disso se explica pela resistência ideológica (talvez principalmente entre os geógrafos humanos) a um estilo de prática científica que tem esse fito de colaborar com a esfera governamental. Porque, assim se dando as coisas, o geógrafo pareceria estar "sujando as mãos", uma vez que cooperando às ações de um qualquer "regime"13.

[...] deveríamos fazer um esforço para que as pessoas que saem da universidade não fiquem todos desempregados. [...] [alguns pensavam que] quando a gente se interessa por uma ciência "para a gestão", corre-se o risco de perder

\footnotetext{
13 Essa espécie de discussão bizantina também se verificou quando da onda repreensiva, nos anos 1960 e 1970, contra a Theoretical and Quantitative Geography, censurada pelos radical geographers por supostamente estar a serviço de governos alinhados com uma lógica capitalista. Esquecendo-se de que, àquela época (e mesmo antes), também o regime socialista soviético se valia dos préstimos de uma geografia mais aplicada, em que não bastava "fazer ciência pela ciência", e era muito bem vista uma razão que empreendesse prognósticos a fim de guiar a ocupação econômica de novos territórios - por exemplo, o da Sibéria (OLDFIELD; SHAW, 2015).
} 
pontos do conhecimento que são importantes, para acentuar apenas o que é "vulgar". A "verdadeira ciência" seria etérea; aquela que não tem tradução no emprego ou no cotidiano. Eu entendo, mas um de meus maiores orgulhos é ter tido doutorandos que logo encontraram postos de trabaIho. [...] [é um falso debate] entre a ciência "fundamental" e a ciência "aplicada". Para mim há a boa ciência e a má ciência. [...] Acho que é normal que a ciência "se rebaixe" para responder à demanda social. O problema é que as pessoas pensam que a pesquisa fundamental é a pesquisa de "alto nível" [...] Se ainda não podemos, do ponto de vista metodológico ou conceitual, aportar uma resposta à sociedade, guardamos essa demanda social. E é isso que vai guiar uma pesquisa teórica. Mas, veja, uma pesquisa "teórica" que vai servir "a alguma coisa"! Dizer "eu faço pesquisa teórica independente de qualquer demanda social" é esnobismo. [DAVID (Entrevista 13 fev. 2017, t.n.)].

\section{UMA ROTA EM TRÊS TEMPOS: A PESCA, O LITORAL, A ILHA}

Num primeiro tempo, a pesca foi seu tema central, com uma análise da atividade haliêutica que, de início, era puramente estatística e narrativa dos esforços locais de produção. Mais tarde, um estudo já sistêmico, globalizante, da pesca artesanal, indo da taxonomia faunística a questões de segurança alimentar. Depois, o litoral ganhou centralidade: seu estudo enquanto "environnement" e análise das provisões aos vilarejos litorâneos. Só ainda depois é que a ilha (antes mero ambiente; negada como "realidade geográfica") ganha o holofote: estudo, então, das migrações do interior ao litoral; análise de políticas públicas para o desenvolvimento e reequilíbrio territorial. Mas estes "três tempos", na verdade, deram-se com temporadas de justaposição - como é frequente ocorrer na história dos cientistas.

Sua rota individual encerra, portanto, as geografias (i) de pesca oceânica - por dez anos contínuos, a contar do início da década de 1980aprox. (mas com "ressurgimentos" a partir da segunda metade dos anos noventa) -, (ii) de ilha - iniciada na transição das décadas de 1980 e 1990, e com apenas uma "pausa" na transição entre os anos noventa e dois mil -, e (iii) de litoral - de estudo praticamente contínuo, a começar de meados da década de 1980. E esse percurso contempla, como se presume, uma sofisticação das abordagens: dos gêneros-de-vida à "vultérabilité à la mondialisation"; dos ecossistemas à "gestion intégrée"; da geografia regional às "politiques publiques de développement" - apuro que adquiriu com a incorporação de novas ferramentas técnicas e conceituais (por exemplo, o outil satellitaire e o géosystème, respectivamente).

Como dissemos, as ilhas, o espaço insular, quase desde o princípio estiveram ali como o ambiente do pesquisador. Direta ou indiretamente presentes em suas investigações, desde muito cedo. Apenas que não constituíam sempre o direto tema de estudo nas ocasiões.

Foi porque David pisava em ilhas, que viria a compreender que não fazia sentido simplesmente estar presente "naquilo" sem se lançar um desafio investigativo. Uma "fraqueza" que não lamentaria reconhecer ter-lhe acometido. 


\title{
Geografias de pesca oceânica (temporada 1983-1991aprox.)
}

Um fator que ilustra a excepcionalidade presente na trajetória dos cientistas pode residir (porque eles não escapam à condição humana) em condicionantes parentais, emocionais. O avô materno e seus tios eram oficiais da Marinha. E a infância de G. David previu frequentes temporadas de ausência do pai - que era marinheiro comercial. Faltas que, por vezes, eram também longas. Este pai, que costumava navegar ao longo da costa brasileira, até o Uruguai e Argentina (cambiando cacau, trigo, sisal) - e tendo chegado mesmo a transportar máquinas frigoríficas de Belém a Manaus -, de certo Ihe figurava como uma espécie de personagem-herói à parte: um homem que, depois de tantos anos na lida de um comércio marítmo inseguro, era ainda capaz de descarregar e recarregar seu barco em menos de nove horas. Mesmo em dias de tempestade. Faltas, enfim, apenas abrandadas quando o pai retornava e Ihe contava as aventuras últimas. Em ocasiões de férias escolares, acontecia do pequeno Gilbert passar alguns dias embarcado com o pai. Podemos, então, deduzir as paisagens que o menino bretão desenhava na cabeça: um distante e enigmático rio Amazonas, as exóticas "cidades-gêmeas" Buenos Aires e Montevidéu, separadas por um não menos excêntrico "rio de prata". E tentando, provavelmente, reouvir o que o pai (Ihe dissera) tinha escutado nos portos de alhures, em suas ruelas vicinais: harpas guaranis, batidas de bossa ao violão, tango ao acordeom. A atração por essas paisagens distantes (agora em versão ainda "inscape") o menino ressentiria quando mais velho: então geógrafo seduzido pelas ideias de "île lointaine", de "terre inconnue". Construções sígnicas que também lhe inspirariam narrativas poéticas.

\begin{abstract}
Para o navio que procura um refúgio para atracar, abordar uma ilha é muitas vezes um perigoso exercício. É preciso navegar longas horas até vislumbrar a passagem entre as ondas de arrebentação e a adjacente angra. Também para o marinheiro originário do continente toda ilha é, antes de mais nada, uma longa costa; hostil, por vezes. Ela até se deixa entrever, mas suas realidades interiores permanecem escondidas. É, portanto, pela imaginação, pelo sonho, que uma ilha é abordada. Porque os olhos são impotentes; condenados a contemplar não mais que a orla do mundo: a interface terra-oceano. (DAVID, 2005b, p. 48, t.n.).
\end{abstract}

David se graduaria em Geografia em 1981, na Universidade da Bretanha Ocidental (UBO), em Brest. Seu trabalho de conclusão (Maîtrise) estaria já associado à área de "Geografia do Mar", tendo defendido uma monografia que teve o Brasil como objeto (DAVID, 1981). Na verdade, uma região e temática bem específicas: a pesca no litoral paraibano (em Cabedelo, mais especialmente; região metropolitana de João Pessoa). A oportunidade de vir ao Brasil se deu graças a um contato com o pesquisador Raymond Pébayle ${ }^{14}$, que coordenara um programa franco-brasileiro que desenvolveu estudos de Geografia e Ecologia na região, e terminou sendo seu orientador na Monografia. Ali, por três meses, David, a princípio, deveria trabalhar a questão da cana-de-açúcar e a transformação do espaço - dados os efeitos dos primeiros anos de implantação do plano "Pró-Álcool"; sobretudo seus custos socioambientais. Mas os planos mudaram. O então regime de generais impôs obstáculo ao acesso e registro

\footnotetext{
14 R. Pébayle (1932-2010) também atuou em várias partes do país, por exemplo no Rio Grande do Sul - onde desenvolveu sua Tese sobre a agropecuária da região (Eleveurs et agriculteurs du Rio Grande du Sul, 1974), que daria depois no livro Les gauchos du Brésil (1977). Pébayle foi autor de livros de divulgação sobre o Brasil, pelos quais recebeu prêmios em função do sucesso editorial (MEDEIROS, 2010). Um deles saiu pela popular coleção "Que Sais-Je?" [Le Brésil. Paris: PUF, 1992. 125p. (n. 628)].
} 
de imagens aéreas da região nordestina; o que era decisivo para levar a cabo suas investigações. Por outro lado, o jovem graduando quarto-anista pôde notar que ali, numa faixa estreita do pequeno distrito paraibano, se passava uma curiosa dinâmica, riquíssima em termos geográficos: um front pioneiro de natureza turística, com já várias residências secundárias, e pescadores vistos obrigados a se deslocar diante daquela pressão do turismo. Esteve interessado em compreender (num corte clássico) as relações homme-milieu, nesta "quase-ilha"; mas também as políticas públicas favoráveis às comunidades locais - o que já apontava um jovem pesquisador sensível ao corte societário das enquetes geográficas. Logo, um profissional gradativamente militante de uma haliêutica tomada por ângulo científico; ou, noutras palavras: buscando sistematizar os conhecimentos capturados junto a coletividades regionais humanas (que, no caso, praticavam a "arte da pesca").

E mesmo quando mudando de cenário investigativo, não seria dada prioritária relevância à problemática da "exploração do recurso", em si; mas antes à da satisfação das necessidades alimentares, ou do desafio das sociedades regionais (por exemplo, da Melanésia e Polinésia) em fazerem frente à mundialização e a catástrofes naturais. Porque nos casos que David testemunharia, parecia que uma estrita descrição dos componentes físicos do litoral tornava-se algo secundário. Era vital aplicar métodos de ordem qualitativa, repousando em observações participativas, sem sacrificar a antiga ambição francesa de uma approche globale.

Mes expériences successives à Vanuatu et en NouvelleCalédonie m'ont montré que l'observation participante était la méthode la plus efficace pour mobiliser rapidement des données [...] (DAVID, 2005a, p. 232).

[...] l'analyse statistique, qui est la première méthode que j'ai employée $[\ldots]$ ne m'a plus guère servie par la suite. [...] j'ai senti le besoin de m'orienter vers des méthodes plus qualitatives ou vers des méthodes quantitatives plus attrayantes comme la cartographie et la télédétection satellitaire. (DAVID, 2005a, p. 312).

Aquela sua iniciação nas abordagens tradicionalistas de gênero-de-vida foram mescladas, de certa maneira, com aportes complementares; os quais, complexificaram a análise: consideração da presença de estrangeiros na coordenação de setores da atividade pesqueira (caso dos baleeiros japoneses na Paraíba). Por outro lado, dado o contexto e a própria inexperiência do jovem David, naquele momento ele se sentia ainda desarmado de conhecimentos que lhe pudessem favorecer um julgamento mais substancial da situação testemunhada. Parecia ser ainda insuficiente sua formação em teoria ecológica ${ }^{15}$. Algo que, no entanto, recuperaria, dada sua (atípica na França) nenhuma resistência às bibliografias anglofônicas ${ }^{16}$.

Logo após a pequena temporada no Brasil, David ruma à Abidjan, na Costa do Marfim, África subsaariana, onde o ORSTOM havia estabelecido um centro de pesquisa oceânica. Lá, desenvolve uma pesquisa que Ihe conferiria um "Diploma de Estudos

\footnotetext{
15 O "problema" da abordagem ecológica na França, no campo geográfico, está relacionado, como se sabe, com algumas ciladas ou querelas (mais ou menos justificadas) que estiveram associadas ao receio de naturalização ou "biologização" das explicações a respeito do desenvolvimento socioeconômico das populações. Uma verdadeira French geographical tradition percebida até pela historiografia anglofônica, que aponta ter se mantido aquecido o debate entre environmental determinism e possibilism até os anos 1960 (JOHNSTON; SIDAWAY, 2016).

16 Uma obra que teve impacto não apenas na prática científica de David, mas numa grande geração de cientistas "híbridos" franceses (interessados, portanto, numa articulação séria entre Ecologia e Economia, p.ex.), foi Ecological economics: the science and management of sustainability, organizado por Robert Costanza (New York: CUP, 1991. 525p.).
} 
Aprofundados" (o "DEA", antigo título francês, quase equivalente ao Mestrado), em 1982, pela mesma UBO. Instalado num vilarejo costeiro, povoado de imigrantes provenientes de Gana e Benin, a ideia seria a de auxiliar tecnicamente a gestão da pesca local - o que, digamos, não configurava exatamente uma "demanda" das autoridades costa-marfinenses, que à época concentravam esforços para a instalação de um porto petroleiro; logo, o que menos queriam era uma pesquisa científica que viesse a valorizar uma "anacrônica" atividade pesqueira. Neste segundo experimento empírico, que também não pôde ser estendido o quanto desejou, por força da conjuntura, o geógrafo, praticando a rigor os protocolos etnográficos, vai descrever a "cadeia operatória" daqueles pescadores em suas oito dezenas de pirogas: suas táticas para a captura das espécies-alvo; a cartografia da localização dos territórios de pesca ... tudo isso partilhando, com aqueles sujeitos em pleno ato, a mesma embarcação; durante longas horas, da madrugada ao amanhecer. Isso marca, de fato, uma relativa ruptura com as abordagens clássicas. Porque há, pela primeira vez, uma atenção menos consagrada ao meio natural (embora não suprimida) e mais devotada ao estudo da chamada "cultura material" - efeito de seu contato com a obra de LeroiGourhan $^{17}$. Mas um segundo notável embaraço nesta experiência lhe viria à mente (percepção que se replicaria em situações futuras): como proceder a um trabalho verdadeiramente interdisciplinar, se os demais especialistas no tema ("pesca") são, por uma previsível cultura de disciplina, refratários ao vocabulário da Geografia?

Se, aliás, nos próprios órgãos de pesquisa e extensão (como seria o caso do ORSTOM) é minoritário o cientista social... - numa clara subvalorização de um domínio disciplinar que, quando ensaiou-se uma tomada de consciência de seu mérito, já teria sido tarde demais. Porque entendamos: além de um desconhecimento público sobre o enquadramento preciso da Geografia, já há, de antemão, uma auto-segregação voluntária (de caráter ideológico, decerto) dos pesquisadores provenientes de ciências humanas com relação aos demais "halieutas". Isolamento que radica ainda em antigos e embaraçantes pré-juízos: que eventuais estudos cooperativos vão ensejar uma hierarquia de forças; e que os cientistas sociais não quererão ingressar num jogo de ações para o qual a sua contribuição não será compensada por uma "humanização" do discurso daqueles profissionais provenientes das ciências naturais. O que é "recurso" para o biólogo pode ser "produto" para o economista ... e tudo isso constituir, afinal, um "espaço" para o geógrafo. Se um especialista esbarra num tema estranho à sua cultura explanatória, ele antes procede a uma transformação deste, de modo a que possa fazê-lo ingressar no seu familiar campo de métodos e conceitos; o que significa: raramente os adaptará ao tema estranho. Isso, além das distinções processualísticas, imperantes dentro mesmo da excêntrica família das ciências humanas ... arqueólogos, etnólogos, sendo mais propensos às démarches indutivistas; enquanto sociólogos e economistas, às dedutivistas?

É claro que a relativa blindagem que advém de uma estrutura disciplinar se verifica já no seio mesmo das instituições político-administrativas - onde, por exemplo, eventuais quadros técnicos associados a planificações da agricultura e do meio ambiente encontram-se em "andares distintos"; ou seja, não intercambiam informação fluida.

David sabia que teria, então, de formular suas próprias representações; sua "épistémologie du littoral": se valendo de uma combinação de métodos que pudesse

\footnotetext{
17 André Leroi-Gourhan (1911-1986), etnólogo francês, aluno do famoso antropólogo Marcel Mauss (1872-1950), foi quem desenvolveu o conceito de "cadeia operatória" (chaîne opératoire) - importante ao desenvolvimento metodológico do trabalho de arqueólogos pré-históricos. O termo aparece no segundo tomo da obra "Le geste et la parole", intitulado "A memória e os ritmos", de 1965 (GALHARDO; FACCIO; LUZ, 2015).
} 
se moldar às realidades observadas; e não o contrário. Transcendendo, portanto, a ideia (afinal paralizante) de aguardar que os pesquisadores em ciências sociais integrem, enfim, a contento, o meio ambiente em suas preocupações; e tão bem quanto biólogos o teriam de fazer, quando cumprindo, por sua vez, a parte que lhes caberia num ideal cenário interdisciplinar: integrar o "humano".

\begin{abstract}
É dizer: "eu faço o esforço para estar no seu nível, mas você não faz o mesmo". E, nesse momento, pareceria haver uma situação de "subordinação". Nossos camaradas das ciências humanas, porque foram bastante nutridos pelas teorias marxistas, viam aí uma relação de "dominador e dominado". Então, eles não queriam ser dominados - o que é absolutamente compreensível. Daí eles preferem escapar da questão; evadir-se dela. Ao invés de discuti-la com [cientistas naturais]. [DAVID (Entrevista 13 fev. 2017, t.n.)].
\end{abstract}

E mais: o próprio fato escalar, que colegas biólogos considerariam como não pertencente ao seu campo disciplinar, e que muitos outros possivelmente entenderiam como desprovido de status científico (a visão de "escala", enfim), não é precisamente o que nos autorizaria a demandar um nicho peculiar para a perspectiva geográfica? Isso porque já seríamos sabedores da inexistência de um método especificamente geográfico; e que sempre o geógrafo utilizará um conjunto de procedimentos em partilha com os campos onde estes foram originalmente concebidos.

Esse início dos anos 1980 também foi decisivo para o transcurso de sua carreira pelo fato de, a partir dessa época, David ter começado a encontrar o Professor Bonnemaison; cuja frequentação abriu caminhos ao nosso personagem.

Por influência e intermediação dele (via contratação junto ao "Ministère des Affaires Etrangères"), David, entre meados e final da década de oitenta, rumaria para as margens do Pacífico Sul, como técnico especialista. Como dizíamos há pouco, o personagem até cogitara permanecer mais tempo na Costa do Marfim; ali prestar seu serviço militar e desenvolver uma Tese de Troisième Cycle. Não tendo sido possível, a solução foi mudar de mares. Literalmente.

\title{
Geografias de ilha (temporada a partir de 1991aprox.)
} insulares ...

Seriam, praticamente, contínuos quinze anos atuando em contextos

David dirigiu-se aos arquipélagos da Melanésia. Vanuatu e, depois, Nova Caledônia sediando seus trabalhos, por temporadas respectivas, em Port-Vila e Nouméa. Em Vanuatu, que havia sido um território híbrido, pertencente à Grã-Bretanha e à França, desembarcaria com o título de expert daquele Ministério. Doravante, se inscreveria em temáticas litorâneas (dando já ignição ao "terceiro tempo" de sua rota); e, em seguida, insulares - âmbitos estes que desenhariam sua produção intelectual a partir de 1991. A sinuosidade da história impõe desvios não desejados, mas também coopera ao surgimento de boas oportunidades inesperadas.

Esta primeira temporada (Vanuatu) forneceu-Ihe o material da Tese de Doutorado - defendida em Junho de 1991, na UBO; tese a respeito da relação entre pesca e segurança alimentar. No final do mesmo ano 1991 David desembarca na Nova Caledônia como "geógrafo encarregado", a serviço do ORSTOM. Teria de dar sequência ali a um programa pluridisciplinar de sugestivo título: "Analyse et Synthèse Régionale" (ASR); que girava em torno de estratégias para o desenvolvimento e reequilíbrio do espaço neo-caledoniano. Tarefa angustiante, de certo modo, posto que o país a re- 
cém saía de um período turbulento de revoltas civis, encerradas em 1988. E dois anos depois encabeceria outro programa oficializado pelo IRD, sendo que dentro de uma Unidade de Pesquisa intitulada "Espaces et Territoires" - o programa "Dinâmica e Gestão de Espaços Insulares Oceânicos"18.

David se ressentiu um pouco de, pela força das contingências, ter de abandonar uma seara de estudos na qual já vinha se especializando (e poderia, então, concentrar esforços). Em nossas conversas, essas "sinuosidades" da história pessoal lhe parecem, às vezes, frustrantes. Se pudesse ter optado, é provável que elegeria conquistar vaga de pesquisador na área de "Geografia da Pesca". E começara mesmo a aguardar por um virtual concurso nestes moldes desde 1985; mas recrutamentos para essa espécie de posto jamais apareceram. "Géographes de la mer" estavam ignorados naquele contexto. E seguiriam sendo: especialidade "exótica" frente aos olhares (aparentemente "mais técnicos" ou operacionais) de um economista ou antropólogo. Ainda que pronunciada em tom humorado, David não disfarça certa mágoa na expressão "punhado de hereges" - dita mais de uma vez, querendo deduzir como ele e outros eram provavelmente vistos por aqueles olhares hegemônicos. Porque, ironicamente, os halieutas provenientes de disciplinas várias e outras, todos, se faziam "geógrafos" de alguma maneira. E pelo simples fato de que viriam a se valer de expedientes de representação gráfica (tais como os mapas temáticos), a fim de proceder à necessária comunicação de suas pesquisas. Todos, afinal, terminavam aproximando-se ... por estarem praticando modernas ferramentas da geomática (tardiamente ingressada na França): o biólogo, o informático, o geógrafo.

Ademais, cada nova expedição se the revelava um novo desafio (nem sempre instigante): reerguer equipes de pesquisa locais já meio moribundas; enfrentar contextos políticos regionais com frequência bastante refratários à "cooperação francesa". Naquele arquipélago da Oceania, Vanuatu, deixaria de ser "geógrafo da pesca" (que lhe parecera ser um caminho fecundo para praticar abordagens integradas); e passava a ser um geógrafo "sócio-economista", analisando antes as perspectivas do turismo e da aquacultura. O programa no qual ali atuaria (o ASR) não previa de fato qualquer componente de ordem marinha ou litorânea. Aquela nova República carecia de apoio científico para que as políticas econômicas (ligadas à pesca, decerto) fossem racionalizadas, e o papel que agora dele se esperava era o de constituir dados sobretudo acerca da organização social do espaço, de modo a diagnosticar o quanto esta organização estaria implicando em que a população mais pobre não estivesse vendo satisfeitas suas necessidades proteicas. Porém, a boa e velha "geografia de campo" não se veria sacrificada; ela, ao contrário, restaria no coração das enquetes e recenseamentos. E chamaria a atenção do cientista especialmente a persistência dos saberes tradicionais - o que Ihe faria reconhecer mais uma vez a necessidade de um ataque pluridisciplinar àquilo que testemunhava. Ou, o quanto seria útil congregar conceitos como os de territorialidade e biodiversidade; aliando-os a noções que a literatura já consagrara: recurso e patrimônio naturais.

Nesta segunda etapa, em que vemos um pesquisador em amadurecimento, notamos a manifestação de certas singularidades reflexivas; por exemplo, a ver com uma ponderação (sobre perdas e ganhos) metodológica: o emprego de indicadores, a comparação de valores obtidos, a identificação de regularidades e dessemelhanças na distribuição espacial - algumas processualísticas muito inerentes ao juízo geográfico, é claro, mas que, em David, redundavam em cuidados sobre o quanto sentir-se encorajado a definir esquemas causais ... se ora as regularidades pareciam incontestes;

18 O governo francês havia decidido dividir o território do país em três províncias: do Norte, do Sul e das Ilhas. A do Sul, onde se situava a capital Nouméa, desejava permanecer francesa; as do Norte e das Ilhas estavam governadas por independentistas. 
ora a disparidade imperava. "Tenho dúvidas sobre a operacionalidade da generalidade" [DAVID (Entrevista 23 jan. 2017, t.n.)]. É verdade que os indicadores haviam trazido a possibilidade de comparar realidades distintas (Vietnã, Madagascar etc.), estimular reflexões e, sem dúvida, multiplicar publicações a respeito. Mas percebeu que não se dava necessariamente um efeito nas gestões em escala local - além do próprio fato de que uma mesma bateria de indicadores nem sempre seria, toda ela, pertinente em qualquer que fosse a realidade estudada. Os feitos "científicos", portanto, poderiam não resultar à altura de suas expectativas. É certo que essa espécie de receio, comum a muitos geógrafos franceses, punha as leituras quantitativas em suspeição ${ }^{19}$ (ainda que não fosse o caso de abrir mão delas): afinal, tratava-se de uma ferramenta única, mas que talvez se mostrasse frágil à pequena escala. Daí que um estilo de ponderação bastante louvável se verificou em David: um qualquer equívoco de escolha podia mesmo pôr em risco toda a validade de um conjunto de estudos que quis ser primoroso. No fim, o clássico impasse de escala era vivenciado.

[...] je me suis herté à un grave problème d'échelle, qui éclaire singulièrement les insuffisances de l'approche qualitative et la difficulté qu'il y a à la combiner avec l'approche quantitative. Comment extrapoler les résultats observés sur un petit nombre de villages, niveau spatial de la démarche qualitative, à l'ensemble du pays, niveau spatial de la démarche quantitative. (DAVID, 2005a, p. 34).

O manuseio das técnicas analíticas exigia certa homogeneização dos dados "de entrada" - logo, uma simplificação sem garantia de que a incontornável "perda de informação" viria acompanhada por uma compensação em termos de significado: "qui dit intégration de l'information, dit sélection des données" (DAVID, 2005b, p. 50). Então, o estudo das ilhas, por exemplo, pressuporia a condição prévia do estabelecimento de um "modelo intelectual de ilha".

Restava a confiança de que a "redução" envolvida, com a captura e reunião dos grandes traços, engendraria ao menos produtos de finalidade pragmática: um mapa genérico. Mas David parece sempre ter tido claro: a realidade mesma não se deixa capturar integralmente pelos instrumentos. E no sentido preciso de que os meios de representação (mobilizados para "espacializar" os dados) não são de fato a análise do espaço. Logo, não bastam para a compreensão do como e do porquê. E daí a razão de trabalhar com a conhecida noção dos "intervales de confiance".

O alinhamento secular do geógrafo francês com o princípio de que suas pesquisas são sempre aquelas desenhadas por uma "situation localisée" (única em seu gênero, ademais) afetou gerações sucessivas. Fatal herdeiro desse tradicionalismo, David foi formado a pensar que mais vale ressaltar os particularismos e as diferenças. Que prudente é desconfiar de toda generalização. Por conseguinte, seríamos espontaneamente levados a pensar ser ilusória toda esperança de deduzir caracteres gerais só porque talvez consigamos mesmo chegar a conhecer bastante satisfatoriamente os detalhes. Por isso, o mais previsível seria que nosso personagem (num espírito, quem sabe, exacerbado pela impressão de isolamento) tivesse preferido levar-se pela imagem de heterogeneidade dos arquipélogos em que esteve - vindo,

\footnotetext{
19 O contato primeiro com a abordagem especialmente numérica data das expedições que antecedem seu doutoramento - ou seja, num momento em que o geógrafo de vinte e poucos anos estudava particularmente a pesca (e cuja atividade produtiva, como se presume, se dava e se dá muito em termos do dado paramétrico "peso"). Daí o entendimento de que havia extrema relatividade em torno do significado daqueles dados - e sobretudo se acontecia de espécies e tamanhos distintos serem tomados de modo indiscriminado nas pesagens.
} 
então, a privilegiar o típico modelo monográfico: pôr à frente toda a "diversité" ali apreendida.

A partir do momento em que os geógrafos se viam diante de uma enorme diversidade, achavam que não valia a pena buscar qualquer critério de generalização no nível espacial. Melhor era trabalhar monografias. Isso fez com que se pensasse que as ilhas não eram um legítimo objeto de pesquisa. Seriam apenas um "espaço" no qual vamos aplicar a geografia urbana, a geografia rural, a geografia ambiental. Não existiria, portanto, uma "geografia das ilhas". Mas eu sim, como aluno e colega de Joël Bonnemaison, considero que ela existe. O problema é que aqueles que perceberam isso não são geógrafos; são antropólogos e economistas. [DAVID (Entrevista 13 fev. 2017, t.n.)].

Os sistemas insulares, se comparados com os continentais, certamente possuem um número bem mais reduzido de elementos em interação, mas, por outro lado, o número de interações é mais expressivo em uma ilha. Em conformidade com a convicção de que era possível e necessário demonstrar que as ilhas configuravam, elas mesmas, uma realidade geográfica; e que o fato poderia ser desenvolvido teoricamente, David afirmou:

Je me range donc résolument dans le clan [...] des croyants en une réalité insulaire qui conduirait à traiter des îles comme des espaces particuliers, différents des espaces continentaux, y compris sur le plan du comportement des populations insulaires. (DAVID, 2005a, p. 175).

Mais recentemente, num contexto em que as instituições privilegiam instâncias onde a globalização opera via atores protagonistas, pesquisadores de instituições como o IRD são estimulados a atuarem junto a "grandes parceiros". Maior aproximação, portanto, de países como o Brasil e a Argentina; menos com as Ilhas Fiji ou Salomão. Logo, as ilhas que outrora pareciam um domínio empírico perfeito para testar ou conceber modelos interpretativos e de intervenção, perderam destaque. "As pessoas de fato não compreenderam por que as ilhas são verdadeiramente um laboratório para compreender as relações entre o meio e a sociedade" [DAVID (Entrevista 13 fev. 2017, t.n.)].

\section{Geografias de litoral (uma longa temporada "de fundo", desde 1985aprox.)}

Os trabalhos em Port-Vila, entre 1988 e 1991, levaram-no à execução de um projeto que, a bem dizer, Ihe reendereçava aos domínios da Geografia: o investimento de esforços na composição de um "atlas da pesca", para o caso Vanuatu. A realização disso levou cerca de três anos, com a produção de mais de duzentos e cinquenta cartas. E uma atuação no centro universitário da capital de Vanuatu lhe permitiu reviver os trabalhos de Bonnemaison - em suas buscas sinônimas por uma resposta às relações "milieu-société". Sem a ambição, no entanto, de chegar à verdade, mas a de interagir com os locais e disso retirar uma informação válida; tal como preconizava o mestre francês da geografia cultural em sua démarche essayiste.

Nessa temporada em Vanuatu teve a ocasião de atuar também como orientador de pesquisas de jovens universitários, junto ao campus local (Port-Vila) da University of the South Pacific - instituição anglófona de ensino, sediada oficialmente nas Ilhas Fiji. Havia uma intenção em que estes vários campi da "USP" pudessem constituir polos regionais de estudos temáticos. Aquele contexto, no entanto, não era muito 
favorável à francofonia, já que a tutela inglesa parecera ganhar destaque pós-independência. Mesmo assim David assumiu o desafio de montar um curso de geografia humana em francês - o que lhe obrigou a fazer adaptações a partir de toda uma literatura majoritariamente anglo-saxônica. No final, uma experiência que lhe permitiu o instigante exercício intelectual de harmonizar bibliografias nacionais que precisavam mesmo complementar uma à outra. A rica abordagem evolucionista sobre civilizações e técnicas (bem aceita e marcada na geografia americana ${ }^{20}$ ) estava ausente dos manuais universitários franceses - por exemplo, do clássico Précis de Géographie Humaine, de Max Derruau. Uma "Université Française" naquela região do Pacífico ("UFP" de Nouméa, Nova Caledônia) só seria instituída já nas cercanias dos anos 1990. David aí ministrou cursos (de geografia do mar e dos litorais), vinculado a um programa de especialização pluridisciplinar criado por colegas antropólogos; programa denominado "Espaço, Tempo e Sociedades no Pacífico Insular", que deveria possuir um tronco comum de corte geográfico. Nosso personagem lamentaria: o programa perdura somente por cinco anos. E todo o seu investimento em despertar geografias de campo, seja na USP, seja na UFP (a fim de oxigenar, regionalmente, sinergias entre planejamento, agricultura, turismo e meio ambiente), viu-se interrompido.

Seu primeiro engajamento no estudo do litoral deu-se sob um ângulo naturalista, a partir de 1985, e por cerca de cinco anos consecutivos. Já entre 1987 e 1994, aproximadamente, ele se dedicaria aos estudos de litorais oceânicos, via teledetecção satelital. Uma sensível, embora provisória, mudança se dá quando David se instala definitivamente em Montpellier. Ali, por alguns anos, a partir de 1998, ele integra um laboratório de estudos rurais, partilhando o ambiente com sociólogos, agrônomos e economistas.

Em final dos anos 1990 participaria de consórcios de pesquisa científica aplicada; por exemplo, atuando como expert principal na área de Geografia, junto ao "GREEN" ("Grupo de Reforço dos Estudos Ambientais Nacionais"). Em Montpellier dá contribuições a um curso de especialização junto à Escola Nacional Superior de Agronomia, ali sediada. Mas no ano de 2001 ele já parte para o centro do IRD sediado em Orléans, onde contribuirá também a formar pós-graduandos num programa universitário dedicado à questão "Planejamento e Desenvolvimento", agora no convívio de ecólogos, antropólogos e arqueólogos. E em meados de 2003 desloca-se de novo para um outro centro IRD: Reunião.

\footnotetext{
${ }^{20}$ Um dos motivos da resistência à literatura americana é a impressão que geógrafos franceses tinham de que essa bibliografia estaria muito próxima de um viés determinista. E isso poderia explicar a pequena inserção dos escritos de Carl Sauer, por exemplo, no círculo daqueles que, na França, dedicavam-se à geografia cultural. Adicionalmente, David nos informou que, quando estudante universitário, muitos de seus Professores não escondiam sua admiração pela perspectiva sustentada pelos geógrafos (à época) "soviéticos": insistindo na máxima da capacidade do homem em suplantar a natureza - concepção replicada na literatura geográfica francesa sob a expressão "mise en valeur de l'espace"; muito provavelmente ventilada na França via textos de Pierre George (1909-2006).
} 


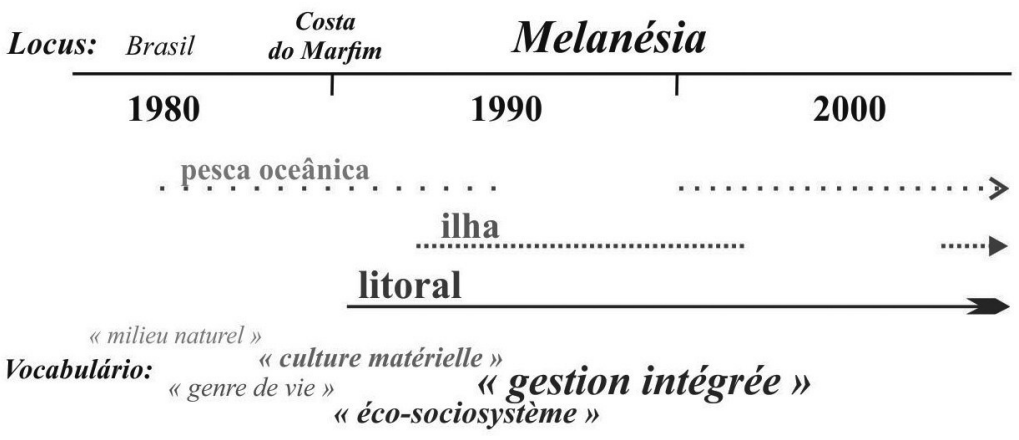

Figura 3 - A rota do indivíduo, em três tempos

[organização nossa]

\section{CONSIDERAÇÕES FINAIS}

Neste artigo tivemos a intenção de sugerir a fertilidade de um campo de análise que resta subexplorado. Assentada na ideia de que uma série mais ampla de tópicos pode conferir maior versatilidade às análises epistemológicas (quer dizer, transcendendo os apontamentos tradicionalistas calcados na sociologia crítica do conhecimento - para os quais já provamos suficiente habilidade), essa fertilidade estaria demonstrada por uma conjunção de aspectos que deveriam, exatamente, ser avaliados "em ligação" ... se concorrem para definir uma dada rota biográfica em ciência.

Os universais a que estivemos aludindo ao longo do artigo, se alçados com atenção, podem ser sumariados aqui nos seguintes cinco tópicos-chave:

1) balanceamento entre o "global" e o "local" - ou, entre o que é padrão e o que parece episódico, excêntrico (uma manifestação especial " $1 a^{\prime}$ " deste tópico, podendo ser a ponderação entre as abordagens quantitativa e qualitativa);

2) percepção das limitações dos instrumentos disponíveis dentro do campo familiar - noutras palavras, o reconhecimento de uma verdadeira insuficiência deles;

3) percepção de campos metodológicos "alienígenas", de outras disciplinas, e incursão junto a eles - uma ação ativada pela consciência de que sofisticações se fazem necessárias [manifestações especiais podendo ser ("3a") a captação e os ensaios com aportes técnicos ou terminológicos que parecerão ser "novos" e ("3b") a descoberta de conceitos híbridos, eventualmente endêmicos aos campos frequentados, mas possivelmente algo equivalentes a termos outros já antes conhecidos (e daí o fato de nosso personagem praticar pesquisas em regime de parceria, e se valer de vocabulário com mote integrador)];

4) pensamento de corte pragmático [compreendendo as manifestações especiais ("4a") da decisão resoluta de praticar uma ciência que oferece solução aos problemas e (" $\left.4 b^{\prime \prime}\right)$ das atitudes e procedimentos sintonizados com, por exemplo, um ideario governamental (e daí o relevo a questões tais como extensão, gestão e serviço)]; e

5) operação relativa de fatores contingentes - considerando, então, que a vida do cientista permanece sujeita aos acasos e aos vaivéns decorrentes do que não se controla ou prefigura. 
Num olhar menos fino, veríamos que se trata de um espectro de temas cujos matizes envolvem perspectivas bastante exploradas por uma literatura a que nem sempre (nós geógrafos latino-americanos) devotamos atenção. Tópicos presentes na produção textual de historiadores e filósofos de outras ciências (normalmente, "naturais"): identidade disciplinar e hibridismo metodológico; produção de conhecimento puro e usos práticos da ciência; psicossociologia da experiência científica (as expectativas, a frustração, a produtividade etc.).

Importante notar que aqueles cinco universais podem agir em simultaneidade; e que, do encontro de alguns, pode derivar uma tendência também expressiva - tal como, numa zona híbrida entre os tópicos 2 e 3, o fato de ser frequente cientistas partilharem uma causa renovadora (reivindivações de mudança teórica, p.ex.) e não necessariamente romperem com certas tradições de seu campo. (Isso estaria claro entre geógrafos franceses que absorveram o ideário sistemista, sem abandonar os cânones empirista e descritivista.). Ademais, por efeito da concomitância, não será simples demarcar se uns universais enquadram-se em âmbito internalista, enquanto outros em externalista. É provável, aliás, que quando um Universal $(U)$ se rebata no caso do indivíduo sob análise (i), o tópico-chave instale-se melhor numa zona de matiz ou escala "cinza"; isto é, mesclando aspectos essencialmente lógicos com indisfarçavelmente sociológicos - o que, de fato, torna a análise epistemológica bastante mais desafiadora e instigante. E isso embora o universal cinco, por exemplo, talvez "sozinho" já fosse especialmente forte em demonstrar que nossa hipótese não é tão sem sentido: exemplares biográficos têm notável serventia para o ensino de Epistemologia - e o exemplar tomado para o exercício não precisa ser dos que constam numa literatura que chancela os "notáveis". (Entendemos que isso foi destacado nas passagens em que nosso personagem protagonista, Gilbert David, foi narrado como um contumaz negociador de controvérsias, estando imerso em respectivas ambientações socioculturais.).

Trabalhados em atividades pedagógicas (que prescreveríamos, então, como em nada estéreis), os universais seriam visibilizados em exercícios de aprendizagem epistemológica. É junto a exemplares livremente selecionados que colheríamos esses universais; e aquelas atividades constituiriam, assim, quase que, digamos, "crônicas (biográficas) da Geografia". Crônicas nas quais um eventual realce aos "lócus de trabalho" também acentuaria, nos parece, o poder explanatório de uma "geografia da ciência geográfica".

Embora Montpellier tenha sido a "geografia" em que nós próprios topamos com o personagem - e aquela cidade, por si só, já legitima realmente a fábula de uma "história local" da ciência (a Montpellier de Sorre ... de Brunet ... de David) - o fato é que nosso protagonista "anônimo" vivenciou uma rota cujo significado foi-se construindo através de muitas geografias: americanas, africanas, oceânicas. E quisemos sugerir que essa trajetória de David serve bem para demonstrar o quanto as experiências realísticas com a prática científica deveriam mais frequentemente nos fazer problematizar o estatuto canônico de algumas questões teóricas. Ou, em outras palavras, o quanto uma crônica das vivências reais poderia melhor instruir (por exemplo, estudantes de Epistemologia) acerca da natureza da ciência. Uma "natureza" que não será negada apenas porque a dimensão concreta das práticas não replica precisamente o que os manuais reflexivos estabelecem; mas, em vez disso, será apresentada em matizes.

Porque a vida profissional dos personagens é o que evidenciaria os limites daqueles universais. 


\section{(U)niversal}

$(\boldsymbol{U})$ :

$$
\underset{\text { ESPECIAIS }}{\stackrel{\text { MANISESTÕ }}{\longrightarrow}}(\boldsymbol{i}) \text { ndivíduo }
$$

[ INTERNALISTA ]

CIENTISTAS RECORREM A INSTRUMENTOS E A RACIOCÍNIOS INFERENCIAIS,

A FIM DE CONCLUIR ACERCA DE UMA CORRESPONDÊNCIA SUFICIENTE E

RACIONAL «REALIDADE--REPRESENTAÇÃO» (OU, «MUNDO--MODELO»).

\begin{tabular}{|c|}
\hline $\begin{array}{l}\text { ABANDONO DE FERRAMENTAS VERIFICADAS COMO IMPOTENTES } \\
\text { PARA A EXPLANAÇÃO DE REALIDADES PROVADAS MAIS COMPLEXAS } \\
\text { (i): OU CAMBIANTES CONFORME A MUDA NCA DE ESCALA DE ABORDAGEM. } \\
\text { IDENTIFICAĊ̃̃O E ALINHAMENTO COM LINGUAGENS RESULTANTES DE } \\
\text { UMA ONDA DE INSATISFACÃO E BUSCA DE APRIMORAMENTOS. }\end{array}$ \\
\hline
\end{tabular}

[ EXTERNALISTA ]

FATORES CONJUNTURAIS TENDEM A DIRECIONAR A PRÁTICA DOS CIENTISTAS,

OFERECENDO-LHE ADITIVOS OU IMPEDITIVOS.

VALORES DE ÉPOCA SE PROJETAM NAS POSTURAS DO CIENTISTA, PODENDO,

INCLUSIVE, AFETAR O CONTEÚDO DAS TEORIAS.

Figura 4 - Atitudes do indivíduo, veiculando universais de matiz hibridizado

[organização nossa]

\section{AGRADECIMENTOS}

Somos extremamente gratos pelo financiamento deste séjour scientifique, proporcionado pelo "JEAI-GITES" (Jeunes Équipes Associées à I'IRD - Gestion, Indicateur et Territoire: Environnement et Santé au Brésil); bem como pela intermediação proporcionada, muito cordial e profissionalmente, pelas pesquisadoras Anne-Elisabeth Laques (IRD/Maison de la Télédétection) e Helen Gurgel (GEA/UnB).

\section{REFERÊNCIAS}

DAVID, G. La pêche sur le littoral de Joao Pessoa à Cabedelo. 165f. Maîtrise (Licence en Géographie) - Université de Bretagne Occidentale, Brest, 1981.

. La vie sur le littoral de Joao Pessoa à Cabedelo, Paraiba. In: CEGET (Dir.). Géographie et écologie de la Paraiba (Brésil): travaux et documents de géographie tropicale. Bordeaux: CEGET, 1983. p. 499-557.

Introduction à la géographie humaine: vol. 2: I'homme sur la terre. Suva: The University of the South Pacific, 1989. 245p.

Pêche villageoise et allimentation au Vanuatu: exploration d'un système. 1051f. Thèse (Doctorat en Géographie) - Université de Bretagne Occidentale, Brest, 1991.

C'est la mer qui prend I'homme. Chronique du Sud, n. 7, p. 105-108, 1992.

Unité et diversité des recherches en sciences humaines consacrées aux petites activités de pêche dans le Pacifique Sud: réflexions épistémologiques et méthodologiques. Nouméa: ORSTOM, 1994. 41p. 
Les sciences humaines et la pêche dans le Pacifique Sud: demande sociale, objectifs et utilité de la recherche. Journal de la Société des Océanistes, v. 106, n. 1, p. 39-56, 1998.

Introduction. In: DAVID, G. (Dir.). Espaces tropicaux et risques: du local au global. Orléans: PUO, 2004. p. 13-22.

Spatialité et temporalité océanes: recherches sur les îles et les rivages de I'Océanie et de la partie occidentale de I'Océan Indien: Livre I: Itinéraire d'un chercheur géographe de la mer et des îles. 2005. 354f. Mémoire (Habilitation à Diriger des Recherches), 3 v. - Unité de Formation et de Recherche en Géographie, Université de Paris IV, Sorbonne, 2005a.

: Livre II: Îles et rivages de I'Indo-Pacifique: variations géographiques. 2005. 428f. Mémoire (Habilitation à Diriger des Recherches), 3 v. - Unité de Formation et de Recherche en Géographie, Université de Paris IV, Sorbonne, 2005b.

DAVID, G. Entrevista. 23 jan. 2017. 00h39min21seg. [Digital Voice Tracer, Philips, model LFH7650].

$\bar{A} 13 \overline{9}]$.

Entrevista. 24 jan. 2017. 01h35min57seg. [dictafone, iPhone 4, model

Entrevista. 13 fev. 2017. 02h58min10seg. [dictafone, iPhone 4, model A1397].

DAVID, G.; RAZAFINDRABÉ, M. Elaboration d'une politique régionale de gestion durable des récifs. Port-Louis: GREEN, 1998. 98p.

DAVID, G. et al. L'aménagement intégré de la zone côtière: propositions méthodologiques. In: Colloque Zones Côtières, Quels Outils, Pour Quelle Géstion? Actes ... Lorient: Université de Bretagne Sud, 2002. 13p.

DAVID, G. et al. La gestion intégrée du littoral récifal de la Réunion: de la connaissance scientifique à l'action publique: jeux d'échelles et jeux d'acteurs. In: Colloque Prospective du Littoral, Prospective pour le Littoral. Actes ... Paris: Ministère de I'Écologie et du Développement Durable, 2005. 16p.

DENEUX, J.-F. Histoire de la pensée géographique. Paris: Belin, 2006. 255p.

DEPREST, F. Nord et sud en France dans les Géographies Universelles (1829-1990): une différenciation à l'épreuve des mutations de la géographie. Revue du Nord, v. 87, n. 360/361, p. 423-440, 2005.

FARACE, D. J.; SCHÖPFEL, J. Introduction : grey literature. In : FARACE ; SCHÖPFEL. (Ed.). Grey literature in library and information studies. Berlin: De Gruyter Saur, 2010. p. 1-7.

GALHARDO, D. A.; FACCIO, N. B.; LUZ, J. A. R. O conceito antropológico de cadeia operatória, sua aplicação e contribuição no estudo de artefatos líticos arqueológicos. Cadernos do LEPAARQ, v. 12, n. 23, p. 5-21, 2015.

GINGRAS, Y. Sociologie des sciences. Paris: PUF, 2013. 127p. (coll. Que Sais-Je?, n. 3950).

GOLDBERG, S. C. Introduction. In: GOLDBERG, S. C. (Ed.). Internalism and externalism in semantics and epistemology. New York: OUP, 2007. p. 1-12.

GOMES, R. A. A. Biografia e geografia da ciência: um estudo a partir da série "Geographers - Biobibliographical Studies". In: SNHCT, 15., 2016. Anais ... Florianópolis: UFSC, 2016. 22p. Disponível em: <http://www.15snhct.sbhc.org.br/site/ anaiscomplementares>. 
JOHNSTON, R. J.; SIDAWAY, J. D. Geography and geographers: anglo-american human geography since 1945. 7. ed. London: Routledge, 2016. 520p.

MEDEIROS, R. M. V. Homenagem póstuma ao professor Raymond Pébayle. Confins, n. 9, jul. 2010. Disponível em: < https://confins.revues.org/6536>.

OLDFIELD, J. D.; SHAW, D. J. B. A Russian geographical tradition?: the contested canon of Russian and Soviet geography, 1884-1953. Journal of Historical Geography, n. 49, p. 75-84, 2015.

PESSOA JR., O. Filosofia \& sociologia da ciência: [aula ministrada]. Campinas: [s.n.], 1993. 10p. Disponível em: <http://opessoa.fflch.usp.br/sites/ opessoa.fflch.usp.br/files/Soc1.pdf>.

POWELL, R. C. Geographies of science: histories, localities, practices, futures. Progress in Human Geography, v. 31, n. 3, p. 309-329, 2007.

ROSEnBerg, A. Philosophy of science: a contemporary introduction. 2. ed. New York: Routledge, 2005. 213p.

SHAPIN, S. Nunca pura: estudos históricos da ciência como se fora produzida por pessoas com corpos, situadas no tempo, no espaço, na cultura e na sociedade e que se empenham por credibilidade e autoridade. Belo Horizonte: Fino Traço, 2013. 552p.

SIMON, D. Quand un concept écologique fait date: I'invention du "complexe pathogène" en géographie. Revue d'Histoire des Sciences Humaines, n. 28, p. 253-272, jan. 2016.

SORRE, M. Les fondements biologiques de la géographie humaine: essai d'une écologie de I'homme. Paris : A. Colin, 1943. 440p. 